\title{
Biomass burning and marine aerosol processing over the southeast Atlantic Ocean: A TEM single particle analysis
}

Caroline Dang ${ }^{1,2}$, Michal Segal-Rozenhaimer ${ }^{3,4}$, Haochi Che ${ }^{3}$, Lu Zhang ${ }^{3}$, Paola Formenti ${ }^{5}$, Jonathan Taylor ${ }^{6}$, Amie Dobracki $^{7}$, Sara Purdue ${ }^{7}$, Pui-Shan Wong ${ }^{8}$, Athanasios Nenes ${ }^{9,10}$, Arthur Sedlacek ${ }^{11}$, Hugh Coe ${ }^{6}$, Jens Redemann ${ }^{12}$,

5

Correspondence to: Caroline Dang (CarolineVanDang@gmail.com) and Michal Segal-Rozenhaimer (msegalro@tauex.tau.ac.il)

${ }^{1}$ NASA Ames Research Center, Moffett Field, California, 94035, USA

Universities Space Research Association, Columbia, Maryland, 21046, USA,

${ }^{3}$ Department of Geophysics, Porter School, Tel Aviv University, Tel Aviv, 69978, Israel

${ }^{4}$ Bay Area Environmental Research Institute, NASA Ames Research Center, Moffett Field, CA, USA

${ }^{5}$ Université de Paris and Univ Paris Est Creteil, CNRS, LISA, F-75013 Paris, France

${ }^{6}$ Department of Earth and Environmental Sciences, University of Manchester, Manchester, UK

${ }^{7}$ Rosenstiel School of Marine and Atmospheric Sciences, University of Miami, Miami, FL, USA

${ }^{8}$ Mount Allison University, Sackville, New Brunswick, CA

${ }^{9}$ Laboratory of Atmospheric Processes and their Impacts, School of Architecture, Civil \& Environmental Engineering, École Polytechnique Fédérale de Lausanne, Lausanne 1015, Switzerland

${ }^{10}$ Center for Studies of Air Quality and Climate Change, Institute of Chemical Engineering Sciences, Foundation for

Research and Technology Hellas, Patras 26504, Greece

${ }^{11}$ Brookhaven National Laboratory, Brookhaven, NY, USA

${ }^{12}$ School of Meteorology, University of Oklahoma, Norman, OK, USA

${ }^{13}$ College of Engineering, Mathematics and Physical Science, University of Exeter, Exeter, UK

${ }^{14}$ Met Office, Exeter, EX1 3PB, UK

\begin{abstract}
This study characterizes single particle aerosol composition from filters collected during the ObseRvations of Aerosols above CLouds and their intEractionS (ORACLES) and CLoud-Aerosol-Radiation Interaction and Forcing: Year 2017 (CLARIFY-2017) campaigns. In particular the study describes aged biomass burning aerosol (BBA), its interaction with the marine boundary layer and the influence of biomass burning (BB) air on marine aerosol. The study finds evidence of BBA influenced by marine boundary layer processing as well as sea salt influenced by BB air. Secondary chloride aerosols were observed in clean marine air as well as in BB-influenced air in the free troposphere. Higher volatility organic aerosol appears to be associated with increased age of biomass burning plumes, and photolysis may be a mechanism for the apparent increased volatility. Aqueous processing and interaction with the marine boundary layer air may be a mechanism for the presence of sodium on many aged potassium salts. By number, biomass burning potassium salts and modified sea salts are the most observed particles on filter samples. These results suggest that atmospheric processing such as photolysis and cloud processing, rather than BB fuel type, has a major role in the elemental composition and morphology of aged BBA.
\end{abstract}




\section{Introduction}

With Africa producing almost a third of the Earth's biomass burning aerosol (BBA) (Roberts et al., 2009), two aircraft campaigns, ObseRvations of Aerosols above CLouds and their intEractionS (ORACLES) and CLoud-AerosolRadiation Interaction and Forcing: Year 2017 (CLARIFY-2017) were focused on understanding African biomass burning aerosol interaction with clouds and radiation in the southeast Atlantic (Haywood et al., 2021; Redemann et al., 2021). The CLARIFY campaign was based near Ascension Island in 2017 and ORACLES was based offshore of Namibia in 2016-2018. CLARIFY findings detail a complex vertical structure which may be due to a temperature inversion which inhibits mixing between layers (Haywood et al. 2021). Over Africa, mixing is inhibited by stable layers at the top of the continental boundary layer (CBL) (Garstang et al., 1996), and over the southeast Atlantic the BBA in the residual CBL moves over the marine boundary layer (MBL) as the air is transported west (Haywood et al. 2021). However, BBA aerosol is more often affected by the MBL than previously accounted for, with BBA reaching the MBL through pathways that are not fully articulated (Zuidema et al., 2018), and entrainment processes through clouds potentially affect aerosol properties. An example of this is the low single scattering albedo in the boundary layer compared to the free troposphere (Zuidema et al., 2018; Pistone et al., 2019). Both campaigns report that a more detailed aerosol process-level understanding including the properties of black carbon, organic carbon and inorganic compounds and how they vary as a function of mixing state and altitude is needed, as is knowledge of properties of the aerosol as they age from emission to deposition and the degree of mixing of BBA into the MBL (Haywood et al. 2021; Redemann et al. 2021).

While in-situ instruments provide data over large temporal and spatial scales, the instruments which analyzed chemical composition in the ORACLES and CLARIFY campaigns analyzed bulk aerosol; detailed off-line single particle analysis can offer valuable information to complement these online measurements. The principal in-situ instrument used in these campaigns to determine aerosol chemical composition is the Aerosol Mass Spectrometer (AMS). The AMS can detect organic and non-refractory inorganic mass at high time resolution. There are limitations on the size range of aerosols detected depending on the inlet system employed, with no detection above one micron and a decreasing efficiency above $700 \mathrm{~nm}$. Salts do not vaporize easily and tend to recombine with oppositely charged ions and make quantification of salts in the mass spectra difficult, if not impossible (Nash et al., 2006). The mixing state of organic and inorganic constituents can only be determined with offline analysis of collected samples rather than insitu bulk aerosol measurements. Transmission electron microscopy (TEM) coupled with energy dispersive X-ray (EDX) is suited to understand physical and chemical properties of individual particles including shape, elemental composition, mixing state, volatility and viscosity, and it is particularly useful for complex aerosol which have been processed (Signorell and Reid, 2011; Reid et al., 2018; Li et al., 2003). Therefore TEM-EDX is a useful method for understanding processes affecting aged BB aerosol as well as marine salts which are pervasive over the ocean.

Previous work of African BBA from SAFARI-2000 showed that the aerosols were primarily composed of black carbon, potassium salts, and organic/sulfur (Liu et al. 2000; Pósfai et al. 2003; Li et al. 2003). The SAFARI campaign 
was mostly focused on BBA that were less aged than particles in CLARIFY and ORACLES. SAFARI results showed that $\mathrm{KCl}$ particles occur in young smoke more often while $\mathrm{K}_{2} \mathrm{SO}_{4}$ and $\mathrm{KNO}_{3}$ particles occur more in aged biomass burning aerosol ( $\mathrm{Li}$ et al. 2003). This is due to gas phase oxidation of $\mathrm{NO}_{\mathrm{x}}$ and $\mathrm{SO}_{2}$ and the displacement of $\mathrm{HCl}$ by the stronger acids $\mathrm{HNO}_{3}$ and $\mathrm{H}_{2} \mathrm{SO}_{4}$ during plume transport. The authors theorized that aging caused sulfate to accumulate on organic and soot particles due to the large amount of internally-mixed soot/sulfate and organic/sulfate in haze (Pósfai et al. 2003). Based on the location and composition of the particles, Pósfai et al. (2003) concluded that organic and soot particles were the main CCN constituents of BBA. SAFARI-2000 samples taken in stratus clouds that capped the boundary layer, distinct from the BB haze layer in the FT, and these samples were dominated by sea salt particles (Pósfai et al. 2003). CLARIFY and ORACLES online observations also show an aerosol population dominated by coated black carbon (BC), organic, and sulfates, consistent with the SAFARI TEM findings of BBA. CLARIFY noted a thick inorganic or organic coating around BC (Taylor et al. 2020); while ORACLES noted a less thick coating around $\mathrm{BC}$ as well as a decreasing amount of coating with plume age (Sedlacek et al. 2021). ORACLES AMS data also noted a decrease in organic with plume age (Dobracki et al. 2021). As the single particle soot photometer, used to detect coatings on $\mathrm{BC}$, does not differentiate between organic and inorganic material, TEM can help elucidate the type and source of coating on BC.

Sea salt aerosol, generated through a bubble bursting process on the sea surface (Lewis and Schwartz, 2004), have implications for radiative effects (Murphy et al., 1998) and cloud condensation nuclei (CCN) activity (King et al., 2012). Sea salt aerosols are modified when they react with sulfate, nitrate, and organic acids, resulting in a Na-rich and Cl-depleted aerosol and emission of gaseous $\mathrm{HCl}$ (Gard et al., 1998). There have been studies on the interaction of urban and anthropogenic sources with marine aerosol (Adachi and Buseck 2015), but single particle studies of sea salt aerosol and variations due to mixing with BB air are scarce. Coastal areas near urban sites show sea salt particles being modified by anthropogenic sources. Adachi and Buseck found that sea salt particles were modified by $\mathrm{H}_{2} \mathrm{SO}_{4}$ and $\mathrm{HNO}_{3}$ by acid displacement of $\mathrm{Cl}$ (2015) and sea salt particles have also been shown to be Cl-depleted by organic acid displacement (Laskin et al., 2012; Kerminen et al., 1998). Pósfai et al. (1995) performed TEM analysis of marine aerosol as part of the Atlantic Stratocumulus Transition Experiment/ marine Aerosol and Gas Exchange (ASTEX/MAGE) campaign and found that polluted continental air affected sea salt aerosol processing, heterogeneity, and mixing with sulfates and nitrates.

With both biomass burning salts and marine salts being major contributors to aerosol in the southeast Atlantic region, a technique that can detect salts is important to accurately represent the aerosol in the region. Further, the plumes sampled during the CLARIFY and ORACLES campaigns are very aged, which is different from previous campaigns such as SAFARI-2000, which was deployed closer to the burning source, and so TEM results can provide information on processing of very aged BBA. This paper will describe the single particle analysis in context of the ancillary data including AMS measurements, back trajectories, cloud processing, time from source and time in the MBL. Our main questions are as follows: (1) what are the aerosols in the region and do CLARIFY and ORACLES aerosol differ from each other based on differences in BB plume age, (2) what are the are differences observed between MBL and FT 
aerosol, (3) what are the mixing states of the aerosol, (4) what are the proposed processes which have acted on the aerosol.

\subsection{Method}

\subsection{Filter Sampling}

Aerosol sampling was performed with the NASA Ames Research Center (ARC) aerosol filter system (AFS), installed on the P3, and the filter system operated on the UK Bae-146 aircraft operated by the Facility of Airborne Atmospheric Measurement (FAAM). Holey carbon TEM grids (Ted Pella, Inc) were attached to $400 \mathrm{~nm}$ hole size polycarbonate nucleopore $400 \mathrm{~nm}$ hole size (WhatmanTM) filters. The Bae-146 has been used for filter analysis for single particle analysis (Chou et al., 2008), as well as bulk analysis (Sanchez-Marroquin et al., 2019; Hand et al., 2010; Andreae et al., 2000). The AFS was composed of a filter holder manifold with five separate filters, connected to the aerosol in situ suite inlet during ORACLES 2017 and 2018. A vacuum pump connected to a flow meter to maintain flow of 30 liters per minute was used for sampling, with five manually controlled valves that were used to switch the sampling to filter holders. The filter manifold was pre-loaded before each flight with filters. Samples for both campaigns were deposited on TEM grids at the locations, sampling times, and total flow volumes listed in Table 1 of the Supplementary Material.

After sampling, the ORACLES 2017 and CLARIFY 2017 filters were sealed in polycarbonate filter holders and wrapped in parafilm paper and aluminum foil and transported together with ice packs in a cooler and placed in a designated freezer immediately at University of Manchester. The ORACLES 2018 filters were sealed in the same manner and transported with ice packs and stored in a designated freezer at Tel Aviv University. A preliminary set of TEM analysis was conducted on the ORACLES and CLARIFY 2017 at the University of Manchester, and then sealed and transported together with ice packs in a cooler for analysis at Tel Aviv University. Care was taken to maintain similar handling, storage, transport, and analysis of all filters in both campaigns. All data included in this study are from the Tel Aviv University analysis.

\subsection{Transmission Electron Microscopy - Energy Dispersive X-Ray Analysis (TEM-EDX)}

145 A JEOL ${ }^{\text {TM }}$ JEM-2010F FEG-TEM with a ThermoNoran ${ }^{\mathrm{TM}}$ energy dispersive X-ray detector (EDX) was used at Tel Aviv University's Exact Sciences' electron microscopy laboratory to analyze 14 filters from CLARIFY (2017) and 16 filters from the ORACLES $(2017,2018)$ campaigns. TEM analysis was performed at $200 \mathrm{KeV}$ accelerating voltage, a take-off angle of 15.9 degrees for X-ray emission from the sample, with an electron beam dwell time of no more than 30 seconds and spot size 3. The filter was scanned visually and representative particles near the center of the TEM grid were analyzed. EDX spectra was collected for each particle and elemental weight percentage and atomic percentage were found per particle and normalized to 100\% using NSS software with Cliff-Lorimer Absorbance correction method. $\mathrm{C}$ and $\mathrm{O}$ are considered semiquantitative due to the contribution from the Formvar film of $\mathrm{C}$ and 
O from the TEM grid. Ratios of elements such as $\mathrm{Na} / \mathrm{S}$ and $\mathrm{Na} / \mathrm{Cl}$ were found by obtaining the either the weight or atomic values for individual particles, finding the ratio of interest, and averaging the ratio per filter.

\subsection{Back-trajectory analysis}

Back trajectories of each sample were generated using the Hybrid Single-Particle Lagrangian Integrated Trajectory (HYSPLIT) model (Stein et al., 2015), with the time step set to one hour. Filter sampling lasted up to approximately ten minutes per filter, and back trajectories were calculated as an ensemble of each minute of filter sampling time. To improve the accuracy of the trajectory, we used the hourly high-resolution ERA5 reanalysis data (fifth-generation atmospheric reanalysis data) to drive the calculation. The ERA5 data is on $0.25^{\circ} \times 0.25^{\circ}$ horizontal resolution and includes 37 pressure levels. We collocated the cloud liquid water content of ERA5 to the coordinates of trajectories, with a threshold of $0.001 \mathrm{~g} / \mathrm{kg}$ to detect clouds on the trajectory. Two collocations were performed: one with the 4-D coordinates of the trajectory (time, longitude, latitude, altitude) and another one with 3-D coordinates (time, longitude, latitude). Thus, the cloud liquid content points and profiles at the trajectory are provided, and the mean time of trajectory inside the cloud (cloud liquid water content $>0.001 \mathrm{~g} / \mathrm{Kg}$ ), and under clear sky (no cloud liquid water above the trajectory) are calculated accordingly. For each sample, we calculated the back trajectories for 1, 2, 3, 5, 7 and 10 days, and the in-cloud and clear sky time correspondingly.

To determine fire locations, fire radiative power (FRP) data was measured by the spinning enhanced visible and infrared imager (SEVIRI) from the geostationary satellite Meteosat-8. The FRP is produced with a 15-min repeat cycle for pixels which contain active burning (Roberts et al., 2005); hourly data was used to match the time step of the trajectory. The age of the $\mathrm{BB}$ aerosol is then estimated as the time in days when the trajectory first intercepts the FRP points, similar to the method used by Vakkari et al. ((Vakkari et al., 2018). The BBA 7-day backtrajectory overlaid with MODIS landcover classifications is included in the Supplementary Material.

\subsection{Aerosol Mass Spectrometer and Single Particle Soot Photometer}

The non-refractive chemical composition for submicron particles was measured using two Aerodyne Time-of-Flight Aerosol Mass Spectrometer (ToF-AMS, Aerodyne Research Inc.), a compact version (C-ToF-AMS) used in CLARIFY (Wu et al., 2020) and a high-resolution (HR-ToF-AMS) used during ORACLES (Dobracki et al. in prep; Redemann et al. 2021). The mass concentrations of organic, sulfate, nitrate, and ammonium were provided. Organic aerosol fractions including f43, f44 and f60 were also derived from the mass spectra obtained during both campaigns. $\mathrm{f} 43$ is the fraction of the measured organic mass at $\mathrm{m} / \mathrm{z} 43$ relative to the total organic aerosol (OA) mass concentration and is indicative of aliphatic carbon chains $\left(\mathrm{C}_{3} \mathrm{H}_{7}+\right)$ and oxygenated fragments $\left(\mathrm{C}_{2} \mathrm{H}_{3} \mathrm{O}+\right)(\mathrm{Ng}$ et al., 2011) common of fragments of aldehydes, ketones, and acid functionalities. Likewise 444 is the fraction of the measured organic mass present at mz44 relative to the total OA mass concentration. The mz44 mass is particularly useful in AMS analysis since it is a result of thermal decomposition of the diacid and organic peroxides on the heater to form $\mathrm{CO}_{2}+$. 

associated with low volatility aerosol (Aiken et al., 2008).

The mass concentration of the refractory black carbon $(\mathrm{rBC})$ of particles ranging from $80-650 \mathrm{~nm}$ was obtained by the single-particle soot photometer (SP2, Droplet Measurement Technologies, Boulder, CO) using laser-induced incandescence. Detailed information on SP2 measurements can be found in Taylor et al. (2020).

\subsection{Results}

\subsection{Overview of observations}

Table 1 shows the conditions in which the filters were collected along with ancillary indicators including latitude and longitude, collection above or below cloud, and AMS data including organic, $\mathrm{SO}_{4} \mathrm{NO}_{3}, \mathrm{NH}_{4}$ and $\mathrm{BC}$ mass and fraction of PM1. Time in-cloud in the 24 hours prior to filter collection and time from fire provide additional context for the sampled aerosols. The gaps in the AMS values are due to quality assurance checks which determined that the data for specific filters are unreliable. In the "time from fire" column, if back trajectory analysis did not show interception with fire but rather a marine source, "marine" is noted in the column. There are more samples taken above cloud, and generally, BC mass values are higher in above cloud samples. 6/14 CLARIFY filters and 3/16 ORACLES filters were sampled in the MBL, with the remainder sampled in the FT. The ORACLES 2017 and CLARIFY 2017 filters were sampled from mid-August to early September, while the ORACLES 2018 filters were collected late September through October. The ORACLES samples, in general, represents aged BBA and CLARIFY samples represent extremely aged BBA.

Figure 1 indicates the location of filter sampling as well as back-trajectories including altitude per filter. As shown by the back trajectories, the filter samples covered different BB sources such as savanna, forest and grasses. CLARIFY sampling was more centered around Ascension Island whereas ORACLES sampling was closer to the African coast with most filters, except for two, sampled during October 2018.

\subsection{Aerosol classifications}

220 The TEM filters showed a heterogeneous aerosol population with variations in mixing for organic, $\mathrm{NaCl}$ salts, potassium salts, and black carbon. $\sim 30-70$ particles on each filter were analyzed to determine composition and particle type. The main particle types including potassium salts, sea salt, black carbon and organic aerosol will be described along with the main findings in the following sections. 


\subsubsection{Organic Aerosol}

The AMS data corresponding to filter collection times show that $35 \%$ to $70 \%$ of CLARIFY and $18 \%$ to $68 \%$ of

ORACLES PM1 is organic, by mass; therefore in-situ data indicates that a substantial amount of PM1 aerosol is organic in both campaigns. While TEM results show organic aerosol for both CLARIFY and ORACLES filters, there is significantly more organic aerosol present on the ORACLES filters. We hypothesize that this is due to differences in the volatility and viscosity of the organic material. Figure 2, left panel, shows a comparison of the fraction of particles, by number, with organic on each filter and the AMS organic fraction, by mass, for the corresponding filter. The majority of CLARIFY filters do not have any particles with organic material, while the majority of ORACLES filters have some particles which contain organic material. As AMS data shows a significant amount of organic aerosol present in both campaigns (Wu et al. 2020; Redemann et al. 2021), the differences in visible organic material on filters can be attributed to loss of volatile organics in the TEM chamber. It is known that volatile species will be lost from particles in a TEM chamber (Pósfai et al. 2003; Hudson et al. 2004) and preferential loss of organic would indicate a comparatively volatile material.

For context, Figure 2, right panel, shows the 443 vs $f 44$ space for the entire ORACLES and CLARIFY campaigns, with filter data overlaid and marked by filter collection below cloud as well as the CO values marked in the colorbar to denote whether the sample is from a BB plume. Both campaigns show a high f44 typical of highly aged organic aerosol, and the ORACLES data show a slightly lower $\mathrm{f} 43$ which is associated with low volatility oxygenated organic aerosol (LV-OOA), although the difference is quite small. Low volatility oxygenated organic aerosol will typically have a lower $\mathrm{f} 43$ and higher $\mathrm{f} 44$ than semi volatile oxygenated organic aerosol (SV-OOA) (Ng et al., 2010, 2011).

TEM has been used to differentiate groups into high contact angle and low contact angle groups where viscosity and volatility of each particle can be qualitatively determined from the particle image. While factors such as surface tension and adhesion forces influence particle shape, viscosity and volatility can still be qualitatively measured on a comparative basis by using electron microscopy images (Reid et al. 2018). Figure 3, top panel, shows a progression from left to right of increasingly volatile organic as imaged by the TEM. The presence of more rounded, viscous organic (Figure 3, top panel, left image) in ORACLES compared to CLARIFY's low contact angle organic (Figure 3, top panel, right image) on the filters is also indicative of relatively higher volatility of organic in CLARIFY filters.

Figure 3, bottom panel, shows the reduction in Org/BC and Org44/BC mass ratios, based on AMS measurements, for both CLARIFY and ORACLES filters as age from biomass burning source is increased. Filters where backtrajectories did not indicate a BB source are included in the "marine" category. It appears that increased age reduces the organic to $\mathrm{BC}$ fraction, similar to the findings of Dobracki et al. (submitted) which found organic aerosol to black carbon mass ratios decreasing from 14 to 10 as the aerosol aged over the Atlantic, indicating a loss in organic aerosol in the BB plumes with age. UV exposure can work to break down oligomers and low-volatility components in organic (Wong 
et al., 2015; Lignell et al., 2014) and may account for lower amounts and/or higher volatility of organic present on CLARIFY filters.

Tar balls are a type of round organic aerosol unique to biomass aerosol and as of now, the only way to identify tar balls has been through microscopy. Tar balls are estimated to contribute up to $\sim 30 \%$ of BB aerosol mass (Sedlacek III et al., 2018). They are highly spherical, high viscosity, and largely resistant to electron beam damage. SAFARI found a considerable number of tar balls (Pósfai et al., 2003) as well as the Biomas Burning Observation Project (BBOP) (Sedlacek III et al., 2018). Adachi et al. (2019) observed tarball formation, likely from primary organic particles, within three hours of emission, with the processing of tar balls possible related to oligemerization of OA. We did not find many tar balls in the CLARIFY and ORACLES campaigns, with the exception of filters corresponding to RF10 and RF11, which were aged for 1 and 2 days, respectively. RF10 had very viscous aerosol but was mixed with considerable amounts of nitrogen and sulfur. This suggests a removal process for tar balls in very aged BB plumes as they are advected west over the ocean.

\subsubsection{Potassium salts and black carbon}

More than $60 \%$ of particles, by number, from the two campaigns were potassium salts, either externally or internally mixed. This is consistent with findings from ( $\mathrm{Li}$ et al., 2003) where organic particles and potassium salts were the predominant particle types in the smoke. The salts were often mixed with black carbon, organic, or sulfates. One very common particle type was potassium salt internally mixed with $\mathrm{BC}$, where the $\mathrm{K}$-salt encapsulates the black carbon in a core-shell configuration. EDX analysis can ablate the salt and leave the refractory black carbon core intact. Another common particle type was organic aerosol with interstitial salts. These two common K-salt mixtures are shown in Figure 4. The coating of BC gives rise to absorption enhancements as discussed by Taylor et al. (2020), where they found universally thickly coated BC, and almost no externally mixed BC. The source of the coating is not described in that paper, and TEM results show that a common coating type is a hygroscopic salt, with implications for both absorption enhancement and enhanced CCN capability of the particles. The three common black carbon mixing states, BC with salt, BC with organic, and externally mixed BC are shown as a fractional amount that exists in each campaign and BL/FT in Table 2. Internal mixing refers to a particle which has two or more separate components, whereas externally mixed particles contain one component per particle. The predominant mixing state is BC internally mixed with salt, however, $\mathrm{BC}$ mixing with organic is likely underestimated due to volatization of organic in the chamber.

\subsubsection{Marine aerosol}

The predominant aerosol on CLARIFY filters are either marine salts or BBA which have been influenced in some manner by the marine atmosphere. The analysis here will focus on CLARIFY aerosol as they show more marine influence than ORACLES. Most CLARIFY filters have sea salt aerosols (SSAs) with $\mathrm{Na}$ and/or Cl present in varying 

seawater. However, $\mathrm{Na}$ and $\mathrm{Cl}$ in the sea salt aerosol rarely exist in a 1:1 atomic ratio, as would be expected from freshly emitted SSA, indicating that the particles have been processed. A schematic of the SSA lifecycle, with representative particles from several CLARIFY filters and example mechanisms for $\mathrm{Cl}$ depletion, is provided in Figure 5. Briefly, freshly emitted sea salt, generated from ocean bubbles bursting, has $\mathrm{Na}$ and $\mathrm{Cl}$ present in a 1:1 atomic ratio. The aerosols are quickly processed in the atmosphere, within the span of hours, with nitrates and sulfates replacing $\mathrm{Cl}$. $\mathrm{S}$ is removed from the atmosphere through oxidation of $\mathrm{SO}_{2}$ in water associated with sea salt particles, and $\mathrm{N}$ species like $\mathrm{HNO}_{3}$ and $\mathrm{NO}_{2}$ are also available for reactions with sea salt. Volatized $\mathrm{Cl}$ can then form new aerosol which does not have $\mathrm{Na}$ present. Variations of $\mathrm{Na}: \mathrm{Cl}$, then, can help determine whether SSA is freshly formed, aged, or very aged based on the degree to which nitrates and sulfates have $\mathrm{Cl}$ present.

Table 3 details CLARIFY filters which have SSA with varying levels of aging, while Table 4 details three filters consisting of $\mathrm{Cl}$-rich aerosol. Both Table 3 and Table 4 list altitude, $\mathrm{CO}$, and time from fire source to provide context as to whether the air mass is $\mathrm{BB}$ influenced. As a measure of aging and sea salt conversion, Table 3 lists $\mathrm{Na}: \mathrm{Cl}$ and $\mathrm{Na}: \mathrm{S}$ weight percent ratios for particles which have those elements present, averaged per filter. Table 4 , as it is based on $\mathrm{Cl}$ aerosol without $\mathrm{Na}$ present, does not list these ratios. Table 3 also lists the percent of particles per filter which contain $\mathrm{Na}$ or $\mathrm{Cl}$, as well as average weight percent of $\mathrm{Na}$ or $\mathrm{Cl}$ in the particles, averaged per filter. For context, $\mathrm{Na}$ and $\mathrm{SO}_{4}$ weight percent in sea salt, based on the composition of sea water, are 60.31 and 7.68, respectively (Seinfeld and Pandis, 2012). Using the atomic weights of sulfur and oxygen, this leaves an expected Na:S ratio of approximately 16:1 in sea salt. A lower than 16:1 ratio indicates $\mathrm{Cl}$ displacement by $\mathrm{S}$ and is and indicator of aerosol aging, therefore based on the ratios in Table 3, our samples are, on average, very aged sea salt.

All SSA in the filters collected in the MBL have $\mathrm{NaCl}$ with varying levels of $\mathrm{Cl}$ depletion. The presence of $\mathrm{Na}$ collocated with $\mathrm{Cl}$ on all below-cloud filters and in only 2/7 of the above-cloud filters suggests the particles are less aged in the BL samples compared to the FT samples. Gold 23, a filter sampled in the FT, has a high $\mathrm{Na}$ :Cl ratio for particles with both $\mathrm{Na}$ and $\mathrm{Cl}$, and this suggests that these salts are aged due to the $\mathrm{Cl}$ depletion. The other filter sampled above-cloud with $\mathrm{Cl}$, Gold8, has mostly $\mathrm{Cl}$-only particles and a few crystals of $\mathrm{Na}: \mathrm{Cl}$ which appear freshly emitted with a cubic $\mathrm{NaCl}$ structure. Cl-only particles in the FT suggests mixing of the MBL and FT, as it shows that $\mathrm{Cl}$ from the ocean has reached the FT through convection or turbulent mixing at the top of the MBL. Unprocessed $\mathrm{NaCl}$ particles in the FT implies a rapid mixing (within hours as this is the average processing time of $\mathrm{NaCl}$ ) of $\mathrm{MBL}$ and FT air associated with the Gold 8 samples. Both Gold8 and Gold23 filters have backtrajectories which show airmasses from the continent which are entirely within the FT, therefore supporting the top-of-BL mixing with FT hypothesis rather than sea salt being present due to airmass transport through the MBL.

In the above-cloud CLARIFY samples, all particles were subject to BB influenced air based on CO values, where we 
present or depleted. There was $\mathrm{BC}$ often mixed with sodium sulfates, $\mathrm{Cl}$, and nitrate, as well as $\mathrm{K}$-salts mixed with $\mathrm{NaSO}_{4}$.

Filter Gold 24, interestingly, shows sodium nitrate mixed with black carbon. N can be difficult to detect in EDX spectra as it is between the $\mathrm{C}$ and $\mathrm{O}$ peaks and can be difficult to deconvolute; therefore the presence of $\mathrm{N}$ in the EDX spectra indicates that there is a substantial amount in the particles. Gold 24 was collected above-cloud and in highly BB-influenced air (331 ppbv of $\mathrm{CO} ; 1.9 \mu \mathrm{g} / \mathrm{cm}^{-3} \mathrm{NO}_{3}$ ). Gold 9, also collected above-cloud in BB influenced air (329 ppbv of $\mathrm{CO} ; 3.1 \mu \mathrm{g} / \mathrm{cm}^{-3} \mathrm{NO}_{3}$ ), also has sodium nitrate but to a lesser extent than Gold 24. As these are the two abovecloud CLARIFY filters with the highest CO levels, and are also the two filters which show some presence of sodium nitrate, this suggests that $\mathrm{BB}$ air may influence the sea salt conversion from $\mathrm{NaCl}$ to $\mathrm{NaNO}_{3}$. This is likely due to the significant amount of $\mathrm{NO}_{\mathrm{X}}$ in the initial $\mathrm{BB}$ plume to form $\mathrm{HNO}_{3}$ and drive $\mathrm{Cl}$ out of the sea salt aerosol. There is also an influence of marine air on BC. For example, the bottom center image in Figure 6 shows a black carbon particle mixed with sodium nitrate from the Gold 24 filter, collected in the FT. The presence of the Na in the FT suggests BB entrainment into the MBL and subsequent mixing of marine air into the FT.

There were different morphologies and compositions of the marine salts due to different salt conversion processes: some large rounded $\mathrm{NaCl}$ over 1.5 micron in diameter and $\mathrm{Ca}, \mathrm{Mg}$, and $\mathrm{Na}$ sulfates and chlorides. Figure 6 shows a few examples of the many different morphologies of marine salts found on the filters. Figure 6 image $\mathrm{F}$ is from Gold 1 which was collected in the MBL, and the particle is BC encapsulated in sodium sulfate; this may be due to aqueous processing where sodium sulfate forms around a BC core. This suggests that while in the FT there is BC and $\mathrm{K}$-salts mixed with sodium, BC, if entrained in the MBL, can also be significantly affected by sea salts and mixed with sodium nitrates and sulfates.

Three filters from CLARIFY, Gold 14, 15 and 18 were dominated by Cl particles which do not have Na present. Table 4 shows the three $\mathrm{Cl}$ dominant filters along with altitude at filter exposure, $\mathrm{CO}$ levels, and time from fire, and Figure 7 provides flight tracks including altitude and particle counts during the filter exposure time. The Cl-rich filters are interesting because of the high spatial density as well as the uniformity of the particles on the filter. The uniform particle composition and morphology of the particles suggests that, per filter, the particles have been subject to similar atmospheric processing. Gold 14 was collected in the FT and backtrajectories show interception with biomass burning six days prior to filter collection. Backtrajectories for filters Gold 15 and 18, both collected in the MBL, show that they do not intercept with the fires and are not as influenced by BB air as Gold 14.

Gold 14 was collected above-cloud, with $47 / 47$ of the particles having strong $\mathrm{Cl}$ and $\mathrm{N}$ peaks, and some of the particles show very minor amounts of Si. Wu et al. (2020) noted an increase in nitrate mass concentration with increasing altitude, and found that the nitrate aerosol mostly existed as ammonium nitrate in the FT. They suggest that the increased levels of nitrate in the FT may be due to colder temperatures at high altitudes which would help partition the $\mathrm{HNO}_{3}-\mathrm{NH}_{3}-\mathrm{NH}_{4} \mathrm{NO}_{3}$ system into the aerosol phase (Wu et al. 2020). Particle counts from the condensation particle 
counter (CPC) show a large increase in particle numbers when the flight C042 increased in altitude from $2250 \mathrm{~m}$ to $2800 \mathrm{~m}$, which may signify an area of newly formed ammonium nitrate as the nitrate partitions into the aerosol phase. As ammonium nitrate is a semi-volatile hygroscopic inorganic salt which can dissolve into the aqueous aerosol phase, we hypothesize that the $\mathrm{Cl}$ aerosols are from $\mathrm{HCl}$ in the gas phase which partitions into the aerosol water and ammonium nitrate aerosol. Relative humidity at filter collection times according to backtrajectories is in the $60-70 \%$ range, which would also help the aerosol become aqueous and the subsequent uptake of $\mathrm{HCl}$. Hydrochloric acid partitioning into aerosol water has also been inferred in urban atmospheres, where the highly water absorbing and soluble chloride in the aqueous phase enhances aerosol water uptake through co-condensation and particle growth, causing haze to form (Gunthe et al., 2021).

Gold 15 was collected below cloud at 329 meters and 21/21 of the analyzed particles were composed predominantly of carbon and chlorine with small amounts of silicon and potassium; the particles appeared very similar across the filter so EDX on additional particles was not performed. These may be $\mathrm{HCl}$ gas uptake onto sea spray aerosol. Gold 18 was collected below cloud at 332 meters. $32 / 32$ particles sampled on the TEM filter were either $\mathrm{CaCl}_{2}$ or $\mathrm{MgCl}_{2}$ with silicon and may have formed through chlorine reacting with $\mathrm{Ca}$ and $\mathrm{Mg}$ in aerosolized sea water.

The high density of the chloride particles on the filters, compared to the other TEM filters, along with the uniform composition and morphology of these particles, suggests either condensation onto new particles formed in the FT or condensation onto marine particles formed from spray in the MBL. While the prevailing view is that new particle formation rarely occurs over open oceans, work by Zheng et al. (2021) shows new particle formation in the remote MBL occurs frequently after the passage of a cold front, with factors such as removal of existing particles by precipitation, vertical transport of reactive gases from the ocean and cold temperatures facilitating new particle formation. Iodine species can also form new particles in pristine regions (He et al., 2021). These conditions do not characterize our sample, however, these studies are part of a growing area of work which supports new particles formation in the remote MBL; if the newly formed particles are aqueous, they can support $\mathrm{HCl}$ uptake and may explain the Cl-dominant aerosol observed.

The filters were collected in both above and below cloud conditions, which suggests a mixing of the MBL and FT, as $\mathrm{Cl}$, either in the gas or aerosol phase, reached the FT after having being emitted from the ocean; air exchange at the top of the BL due to turbulent mixing may be for the cause of this, particularly as there is a transition from stratocumulus to cumulus near Ascension Island, and a corresponding increase in convection (Gordon et al., 2018). We hypothesize that $\mathrm{Cl}$ in the $\mathrm{FT}$ may be from $\mathrm{HCl}$ in the $\mathrm{BL}$ which gets taken up into cloud droplets, and on their evaporation at cloud top is re-released onto more neutral aerosol such as ammonium nitrate. 
The MBL had a large effect on BB aerosols and as well as processing of sea salt aerosols. A comparison of cloud processing and time in the FT and MBL for the aerosol collected during the filter sampling time is provided in Figure 8. The filters are segregated by collection in the MBL and FT and the fractional time spent in each environment is shown in Panels B (collected in BL) and D (collected in FT). Panel D shows that aerosols collected in the FT, irrespective of campaign, have spent nearly all their time in the FT. Panel B shows that of filters sampled in the BL, CLARIFY aerosols have spent more than $80 \%$ of the fractional time spent in the BL in the day before filter sampling compared to ORACLES' $45 \%$.

The cloud processing intensity, which is the mean cloud liquid water content multiplied by the mean in-cloud time, in the days prior to the airmass reaching the downwind filter collection location is provided in Figure 8 Panel A. Aerosols collected in the MBL were subject to more cloud processing than those collected in the FT, as the aerosols would need to be entrained into BL. ORACLES aerosol, on average, spent slightly more time in-cloud and with clouds with a higher liquid water content than CLARIFY aerosol, particularly apparent for those filters collected in the MBL.

In sea salt, $\mathrm{K}$ weight percent is 1.1 , assuming sea salt has the composition of seawater and ignoring atmospheric processing (Seinfeld and Pandis, 2012). The K-salt from BB has a significantly higher weight percent than the minor amounts of $\mathrm{K}$ found in seawater and sea salt. The fraction of $\mathrm{K}$-salt mixed with sodium increases with age, as shown in Figure 8 Panel C. This implies that the K-salt from biomass burning is processed in a way which allows $\mathrm{Na}$ incorporation into the particle. As $\mathrm{Na}$ is not volatile at atmospheric pressures, we hypothesize that the mechanism is processing by particle mixing, either by cloud drop coalescence or drizzle wash out of aerosol and evaporation.

The interaction of the MBL with BBA and the effect of BB air on marine aerosol has been shown in previous sections, and we hypothesize the mixing of Na salts with BBA to be due to aqueous processing and particle mixing through, for example, cloud drop coalescence. An aqueous K-salt particle from CLARIFY's Gold 9 filter is presented in Figure 9. It has varying $\mathrm{Na}: \mathrm{K}$ ratios by weight percent, designated in the red circles, and there is no $\mathrm{Cl}$ in the particle. We assume that the $\mathrm{Na}$ present is from marine sources because the area with an $11: 1$ ratio has $13 \mathrm{wt} \% \mathrm{Na}$ but only 1.2 $\mathrm{wt} \% \mathrm{~K}$; this is a higher $\mathrm{Na} w \mathrm{t} \%$ than would typically be expected from BBA. However, it should be noted that $\mathrm{Na}$ may also be from biomass burning, as sodium has been noted in BB fuel, with the type influencing the amount of $\mathrm{Na}$ in particles (Hudson et al., 2004). The image shows that Na mixes with K-salts, organic and sulfur in varying degrees throughout a single aqueous particle and therefore this is a potential mechanism for $\mathrm{Na}$ incorporation into existing $\mathrm{K}$ salts. condensation nuclei. Figure 10 shows $\mathrm{BC}+\mathrm{K}$-salt (top panel) and $\mathrm{BC}+($ organic/sulfur) mixtures as a function of 
time in cloud encountered one day before sampling. The spherical nodules are black carbon and the more reflective white areas in the bottom panel are the sulfur/organic mixture. Each particle ID shows the TEM image and associated time in cloud (hours) in the day before sampling, the mean liquid water content of the clouds $(\mathrm{g} / \mathrm{kg})$ in the day before sampling, and the weight percent of elements in the particle. From left to right, the time in-cloud increases. If the electron beam visibly altered the particle, an "after" image is shown along with an "before" image to indicate the particle's response to the electron beam. In each particle, the black carbon is insoluble and appears unaffected by increased cloud processing; however, both the K-salts and the sulfur/organic appear affected by increased time in cloud. In the left most panel for Figure 10, top panel, the K-salt is completely unaffected by exposure to the electron beam. The other images in Figure 10 show electron beam damage, indicating that these K-salt structures are more susceptible to volatilization and degradation due to the electron beam; this may be due to degradation of the K-salt during cloud processing. The K-salt particles on the right, which were subject to the most time in cloud, have a less distinct morphology which may indicate periods of water uptake and loss. In Figure 10, bottom panel, the sulfurorganic constituent of the aerosol which was subject to the least about of time in-cloud appears to have high viscosity, and was unaffected by the electron beam. After more time in cloud, the sulfur/organic on these particles appear to have a lower viscosity, to be more flat, and also to be more affected by the electron beam. Although these are only a few particles, the images imply that cloud processing can affect certain constituents of mixed aerosols more than others; the structure of the K-salt and the viscosity of the sulfur/organic mixture appear to be more affected by aqueous processing compared to $\mathrm{BC}$.

\subsection{Elemental mixing in individual particles}

EDX of individual aerosol particles can provide information on elemental mixing across the entire ORACLES and CLARIFY sample sets. Figure 11 shows the elemental mixing of CLARIFY and ORACLES samples collected in the free troposphere and boundary layer, designated in separate columns, with each row of pie charts indicating whether a set of two elements are collocated on individual particles for all particles of the specified particle set. All percentages are based on particle numbers rather than mass. The elements $\mathrm{S}, \mathrm{Na}, \mathrm{Cl}$ and $\mathrm{K}$ were chosen for elemental mixing analysis as they are the elements which most commonly appear in the EDX spectra. $\mathrm{C}$ and $\mathrm{O}$ are found in the spectra of almost all particles, and so these elements are not included in this analysis.

A higher fraction of ORACLES aerosol contains S, 80\%, compared to CLARIFY's 40\%. Three quarters of CLARIFY particles which contain $\mathrm{S}$ also contain $\mathrm{Na}$, while most ORACLES particles contain $\mathrm{S}$ without $\mathrm{Na}$ present. $\mathrm{S}$ is mixed with $\mathrm{K}$ in $34 \%$ of CLARIFY and $73 \%$ of ORACLES aerosols. This suggests that ORACLES S is predominantly from biomass burning as it is collocated with $\mathrm{K}$, and potassium is frequently used as a marker for BBA, consistent with the high amounts of K-salts observed in TEM samples. 76\% of ORACLES FT aerosol contain collocated $\mathrm{S}+\mathrm{K}$, compared with $59 \%$ of ORACLES BL aerosol. In comparison, $35 \%$ and $33 \%$ of CLARIFY FT and BL aerosols have collocated S+ K, respectively, implying a dilution of BBA in the CLARIFY aerosol population collected on filters, in comparison to ORACLES. 
$70 \%$ of CLARIFY aerosols and 33\% of ORACLES aerosol contain some combination of $\mathrm{Cl}$ and/or Na. Of ORACLES aerosols containing $\mathrm{Na}$, only a minor fraction is mixed with $\mathrm{Cl}$, compared with $20 \%$ of CLARIFY particles containing both $\mathrm{Na}$ and $\mathrm{Cl}$. $\mathrm{Cl}$ can be found in fluids of some vegetation and so can be present in BBA (Liu et al. 2000), thus while ORACLES Cl may be due to either biomass burning or a marine influence, it is likely that the high fraction of CLARIFY particles with $\mathrm{Cl}$ present, relative to the ORACLES population, is indicative of a marine influence. This is also supported by the difference in CLARIFY $\mathrm{Cl}$ in the $\mathrm{BL}$ ( $75 \%$ of particles) versus the FT ( $31 \%$ of particles), as well as CLARIFY filters Gold 14, 15 and 18 which were dominated entirely by $\mathrm{Cl}$ particles.

$81 \%$ of ORACLES and $54 \%$ of CLARIFY aerosols have K present. $22 \%$ of CLARIFY aerosol contain collocated K and $\mathrm{Cl}$, while $\mathrm{Cl}$ is present, with or without $\mathrm{K}$, in only $3 \%$ of ORACLES aerosol. S mixed with $\mathrm{Cl}$ is present in $15 \%$ of CLARIFY and 3\% of ORACLES aerosol. ORACLES aerosols contain a much lower fraction of Cl-containing particles than CLARIFY.

$44 \%$ of CLARIFY aerosol contains Na compared to $30 \%$ of ORACLES aerosol. $38 \%$ of CLARIFY aerosols have Na collocated with K, versus $26 \%$ of ORACLES particles. $56 \%$ and $17 \%$ of ORACLES and CLARIFY aerosols contain $\mathrm{K}$ but no Na, respectively. Following trends pointed out earlier, $\mathrm{Na}$ is present in relatively more CLARIFY aerosol than ORACLES.

The higher number of particles with S present in ORACLES samples, particularly the FT, may indicate a higher fraction of BBA (because it is collocated with K) compared to CLARIFY, or more sulfate aerosol formation via cloud processing. Studies have shown formation of sulfate to be related to cloud processing (Ervens et al., 2018), and ORACLES samples were subject to higher amounts of cloud processing than CLARIFY samples.

The high amounts of $\mathrm{Na}$ and $\mathrm{Cl}$, both separate and collocated in CLARIFY samples, particularly the BL, suggests a high amount of marine boundary layer influence and marine salts. While the majority of particles in both CLARIFY and ORACLES contain $\mathrm{K}, \mathrm{K}$ largely exists independently of $\mathrm{Cl}$ in the ORACLES samples, while it is mixed with $\mathrm{Cl}$ for a substantial fraction of CLARIFY particles particularly in the BL where $42 \%$ of particles contain collocated $\mathrm{K}+$ Cl. Similarly, $\mathrm{S}$ exists largely without $\mathrm{Cl}$ in ORACLES particles but is collocated with $\mathrm{Cl}$ in $27 \%$ of CLARIFY particles. This implies gas phase $\mathrm{Cl}$ condensation onto BBA, particularly $\mathrm{K}$-salts, in CLARIFY aerosol. There is also a substantial difference in the amount of Na collocated with $\mathrm{K}$ in the FT and BL for both ORACLES and CLARIFY campaigns: CLARIFY FT 35\%, BL 43\%; ORACLES FT 22\%, BL 50\%. The majority (59\%) of ORACLES FT particles contain $\mathrm{S}$ independent of $\mathrm{Na}$; however, of the ORACLES samples collected in the $\mathrm{BL}, 46 \%$ of the particles contain S collocated with Na. This implies, again, a marine boundary layer influence in the increased Na-containing particles in the BL for both campaigns. Assuming that BBA is in the FT and then becomes entrained in the BL, this transition could help facilitate aqueous processing and particle mixing through droplet coalescence in cloud and evaporation, which would incorporate $\mathrm{Na}$ onto the BBA. 


\subsection{Conclusions}

This work combines online field measurements and TEM analysis of two campaigns with disparate aging of BBA aerosol. Detailed single particle analysis revealed considerable heterogeneity in the aerosol population of CLARIFY and ORACLES filters in terms of mixing of elements and processing of individual particles. We find similarities to the previous major campaign which analyzed African BBA, SAFARI-2000, in that we find an abundance of potassium salts, black carbon, and organic carbon with interstitial potassium salts (Pósfai et al., 2003; Li et al., 2003). While SAFARI noted an abundance of potassium salts, our TEM analysis shows for the first time in the region that a large fraction of $\mathrm{BC}$ is internally mixed with potassium salts. This has implications for radiative effects due to lensing as well as CCN capability due to the hygroscopicity of the salt. While SAFARI analysis found abundant $\mathrm{KCl}$ near source, both the CLARIFY and ORACLES campaign are in areas measuring much more aged aerosol, and our results show that $\mathrm{KCl}$ was not widely found. This is presumably because replacement of $\mathrm{Cl}$ by nitrates and sulfates has occurred. Near Ascension Island, Cl, likely from marine sources rather than biomass burning, was present on a large number of particles. While the SAFARI campaign and other recent biomass burning campaigns note a considerable amount of tar balls, our TEM analysis did not observe many other than on filters RF10 and RF11, which were aged for approximately 1 and 2 days, respectively. ORACLES and CLARIFY aerosol are generally very aged, and so this finding implies a reduction in tar balls in very aged BB plumes.

SAFARI was near source and focused on BBA, and online AMS and SP2 analysis for CLARIFY and ORACLES was focused on nitrates, sulfates, organic, BC and ammonium. Our TEM analysis extends this data set through the finding of an abundance of marine salts with varying levels of processing. In general, sea salt aerosol collected in the MBL were less aged than those in the FT, as evidenced by $\mathrm{Cl}$ depletion. $\mathrm{Cl}$ was mostly, but not always, depleted in the FT compared to aerosols found in the MBL which had higher levels of $\mathrm{Cl}$. The presence of $\mathrm{Cl}$ and, on some filters, freshly emitted $\mathrm{NaCl}$ in the free troposphere suggests mixing of the MBL and FT in some regions, likely through convection and turbulent mixing at the top of the BL.

We found evidence of BBA interaction with the MBL as well as marine salts affected by BB air, which has not been as of now reported in these campaigns. Mixing of marine air with BB air affects sea salts because of $\mathrm{Cl}$ replacement by nitrate, as the BB plumes had elevated levels of NOx to drive Cl out of the SSA. Reciprocally, BBA was influenced through, for example $\mathrm{BC}$ mixing with sodium sulfates and sodium nitrates and the presence of $\mathrm{Na}$ on large number of BB particles.

We found high levels of $\mathrm{Cl}$ collocated with $\mathrm{K}$ and $\mathrm{S}$ in CLARIFY aerosol, particularly those collected in the MBL, and this suggests $\mathrm{Cl}$ gas species condensation or $\mathrm{HCl}$ uptake onto BB K-salts. The uniformity and ubiquity of $\mathrm{Cl}-$ containing aerosol particles on three CLARIFY filters suggests that particles on these filters have been uniformly processed and the existence of areas dominated by $\mathrm{Cl}$ aerosol. Further, the high density of $\mathrm{Cl}$ spatially on these filters implies $\mathrm{HCl}$ condensation onto existing particles which have been recently formed and processed uniformly. 
There is considerable mixing of Na with BBA through what we believe is aqueous processing of particles, through, for example either cloud drop coalescence or drizzle washout of aerosol and subsequent evaporation. TEM particles show evidence of aqueous processing, with varying ratios of soluble components throughout a single particle. Particle morphology also show evidence of cloud processing, with soluble components more significantly affected by time in cloud than insoluble components such as black carbon.

TEM analysis indicates an increase in organic aerosol volatility with BB plume age based on the higher fraction of organic which evaporated in the TEM chamber in CLARIFY compared to ORACLES. Che et al. (submitted) noted SOA formation in the first $\sim 70$ hours of BB aging; our results suggest that the secondary organic which forms may be more volatile than the initial organic emitted from biomass burning. There have been different explanations for the vertical structure of single scattering albedo near Ascension Island, with Taylor et al. (2020) and Wu et al. (2020) suggesting a partitioning of inorganic ammonium nitrate onto existing particles at colder temperatures, and Dobraki et al. (2021) hypothesizing that the SSA differences are due to scattering organic material that is lost from BBA. Sedlacek et al. (2021) also found a loss of organic material coating BC with plume age in ORACLES; further the authors define different regimes for BBA where organic coating on black carbon increases in the first few hours after emission, the coating mass then plateaus after a several hours to several days when there are competing chemical physical processes such as photochemistry, SOA production, fragmentation and oxidation, and after several days of aging there is material loss due to cloud processing, volatility, and bleaching of brown carbon. While there are different explanations for the vertical structure of single scattering albedo near Ascension Island as well as mechanisms for organic loss with age, our results indicate that higher volatility organic is associated with aging; therefore we hypothesize that photolysis and fragmentation of carbon chains in the organic is the predominant mechanism for the apparent higher volatility of aged organic.

While studies on combustion types show differences in primary particle types in terms of mixing, amount of organic and elemental composition, for example for particles formed in the flaming and smoldering phase (Liu et al. 2017), these studies are for fresh particles, unlike the very aged combustion aerosol found in ORACLES and CLARIFY. Due to the considerable processing of organic aerosol and the noted effects of the MBL on BBA, it appears that aqueous processing, photolysis, and interaction with the MBL are the key drivers in physical and chemical properties such as mixing state and elemental composition of very aged BBA, rather than source.

\section{Data Availability}

Data are publicly available at the ORACLES and CLARIFY archives: http://data.ceda.ac.uk/badc/faam/data/2017

and https://espo.nasa.gov/oracles/archive/browse/oracles/id14. Data not on this website can be provided by request.

\section{Author contribution}

MS, H. Coe, and CD designed the research. JH, H. Coe, JR, PZ, AN are PIs of the campaigns. JT, MSR, PW, SP, PZ, AN performed field work or provided support for filter collection. CD performed laboratory analysis. CD and 
595 H. Che provided figures. CD, H. Che, MS and LZ analyzed data sets. CD led the paper writing, and all co-authors contributed to ideas and writing.

\section{Competing interests}

The authors declare that they have no conflict of interest.

600

\section{Acknowledgements}

The first author was supported by the NASA Postdoctoral Fellowship Grant. ORACLES is a NASA EARTH Venture Suborbital-2 investigation, funded by the US National Aeronautics and Space Administrations (NASA)'s Earth Science Division and managed through the Earth System Science Pathfinder Program Office (grant no. NNH13ZDA001N-EVS2). CLARIFY-2017 was a Natural Environment Research Council (NERC) Large Grant NE/L013584/1. PF is supported by the AErosols, RadiatiOn and CLOuds in southern Africa (AEROCLO-sA) project funded by the French National Research Agency under grant agreement $n^{\circ}$ ANR-15-CE01-0014-01, the French national programs LEFE/INSU and PNTS, the French National Agency for Space Studies (CNES), the European Union's 7th Framework Programme (FP7/2014-2018) under EUFAR2 contract n³12609, and the South African National Research Foundation (NRF) under grant UID 105958. 


\section{References}

Adachi, K., Sedlacek, A. J., Kleinman, L., Springston, S. R., Wang, J., Chand, D., Hubbe, J. M., Shilling, J. E., Onasch, T. B., Kinase, T., Sakata, K., Takahashi, Y., and Buseck, P. R.: Spherical tarball particles form through rapid chemical and physical changes of organic matter in biomass-burning smoke, Proc. Natl. Acad. Sci., 116, 19336-19341, https://doi.org/10.1073/pnas.1900129116, 2019.

Aiken, A. C., DeCarlo, P. F., Kroll, J. H., Worsnop, D. R., Huffman, J. A., Docherty, K. S., Ulbrich, I. M., Mohr, C., Kimmel, J. R., Sueper, D., Sun, Y., Zhang, Q., Trimborn, A., Northway, M., Ziemann, P. J., Canagaratna, M. R., Onasch, T. B., Alfarra, M. R., Prevot, A. S. H., Dommen, J., Duplissy, J., Metzger, A., Baltensperger, U., and Jimenez, J. L.: O/C and OM/OC Ratios of Primary, Secondary, and Ambient Organic Aerosols with HighResolution Time-of-Flight Aerosol Mass Spectrometry, Environ. Sci. Technol., 42, 4478-4485, https://doi.org/10.1021/es703009q, 2008.

Andreae, M. O., Elbert, W., Gabriel, R., Johnson, D. W., Osborne, S., and Wood, R.: Soluble ion chemistry of the atmospheric aerosol and SO2 concentrations over the eastern North Atlantic during ACE-2, Tellus B Chem. Phys. Meteorol., 52, 1066-1087, https://doi.org/10.3402/tellusb.v52i4.17087, 2000.

Chou, C., Formenti, P., Maille, M., Ausset, P., Helas, G., Harrison, M., and Osborne, S.: Size distribution, shape, and composition of mineral dust aerosols collected during the African Monsoon Multidisciplinary Analysis Special Observation Period 0: Dust and Biomass-Burning Experiment field campaign in Niger, January 2006, J. Geophys. Res. Atmospheres, 113, https://doi.org/10.1029/2008JD009897, 2008.

Ervens, B., Sorooshian, A., Aldhaif, A. M., Shingler, T., Crosbie, E., Ziemba, L., Campuzano-Jost, P., Jimenez, J. L., and Wisthaler, A.: Is there an aerosol signature of chemical cloud processing?, Atmospheric Chem. Phys., 18, 16099-16119, https://doi.org/10.5194/acp-18-16099-2018, 2018.

635 Gard, E. E., Kleeman, M. J., Gross, D. S., Hughes, L. S., Allen, J. O., Morrical, B. D., Fergenson, D. P., Dienes, T., Gälli, M. E., Johnson, R. J., Cass, G. R., and Prather, K. A.: Direct Observation of Heterogeneous Chemistry in the Atmosphere, Science, 279, 1184-1187, https://doi.org/10.1126/science.279.5354.1184, 1998.

Garstang, M., Tyson, P. D., Swap, R., Edwards, M., Kållberg, P., and Lindesay, J. A.: Horizontal and vertical transport of air over southern Africa, J. Geophys. Res. Atmospheres, 101, 23721-23736, https://doi.org/10.1029/95JD00844, 1996.

Gordon, H., Field, P. R., Abel, S. J., Dalvi, M., Grosvenor, D. P., Hill, A. A., Johnson, B. T., Miltenberger, A. K., Yoshioka, M., and Carslaw, K. S.: Large simulated radiative effects of smoke in the south-east Atlantic, Atmospheric Chem. Phys., 18, 15261-15289, https://doi.org/10.5194/acp-18-15261-2018, 2018.

Gunthe, S. S., Liu, P., Panda, U., Raj, S. S., Sharma, A., Darbyshire, E., Reyes-Villegas, E., Allan, J., Chen, Y., Wang, X., Song, S., Pöhlker, M. L., Shi, L., Wang, Y., Kommula, S. M., Liu, T., Ravikrishna, R., McFiggans, G., Mickley, L. J., Martin, S. T., Pöschl, U., Andreae, M. O., and Coe, H.: Enhanced aerosol particle growth sustained by high continental chlorine emission in India, Nat. Geosci., 14, 77-84, https://doi.org/10.1038/s41561-020-00677$\mathrm{x}, 2021$.

Hand, V. L., Capes, G., Vaughan, D. J., Formenti, P., Haywood, J. M., and Coe, H.: Evidence of internal mixing of African dust and biomass burning particles by individual particle analysis using electron beam techniques, J. Geophys. Res. Atmospheres, 115, https://doi.org/10.1029/2009JD012938, 2010.

Haywood, J. M., Abel, S. J., Barrett, P. A., Bellouin, N., Blyth, A., Bower, K. N., Brooks, M., Carslaw, K., Che, H., Coe, H., Cotterell, M. I., Crawford, I., Cui, Z., Davies, N., Dingley, B., Field, P., Formenti, P., Gordon, H., de Graaf, M., Herbert, R., Johnson, B., Jones, A. C., Langridge, J. M., Malavelle, F., Partridge, D. G., Peers, F., Redemann, J., Stier, P., Szpek, K., Taylor, J. W., Watson-Parris, D., Wood, R., Wu, H., and Zuidema, P.: Overview: The CLoud- 
Aerosol-Radiation Interaction and Forcing: Year-2017 (CLARIFY-2017) measurement campaign, Atmospheric Chem. Phys. Discuss., 1-49, https://doi.org/10.5194/acp-2020-729, 2020.

Haywood, J. M., Abel, S. J., Barrett, P. A., Bellouin, N., Blyth, A., Bower, K. N., Brooks, M., Carslaw, K., Che, H., Coe, H., Cotterell, M. I., Crawford, I., Cui, Z., Davies, N., Dingley, B., Field, P., Formenti, P., Gordon, H., de Graaf, M., Herbert, R., Johnson, B., Jones, A. C., Langridge, J. M., Malavelle, F., Partridge, D. G., Peers, F., Redemann, J., Stier, P., Szpek, K., Taylor, J. W., Watson-Parris, D., Wood, R., Wu, H., and Zuidema, P.: The CLoud-AerosolRadiation Interaction and Forcing: Year 2017 (CLARIFY-2017) measurement campaign, Atmospheric Chem. Phys., 21, 1049-1084, https://doi.org/10.5194/acp-21-1049-2021, 2021.

He, X.-C., Tham, Y. J., Dada, L., Wang, M., Finkenzeller, H., Stolzenburg, D., Iyer, S., Simon, M., Kürten, A., Shen, J., Rörup, B., Rissanen, M., Schobesberger, S., Baalbaki, R., Wang, D. S., Koenig, T. K., Jokinen, T., Sarnela, N., Beck, L. J., Almeida, J., Amanatidis, S., Amorim, A., Ataei, F., Baccarini, A., Bertozzi, B., Bianchi, F., Brilke, S., Caudillo, L., Chen, D., Chiu, R., Chu, B., Dias, A., Ding, A., Dommen, J., Duplissy, J., Haddad, I. E., Carracedo, L. G., Granzin, M., Hansel, A., Heinritzi, M., Hofbauer, V., Junninen, H., Kangasluoma, J., Kemppainen, D., Kim, C., Kong, W., Krechmer, J. E., Kvashin, A., Laitinen, T., Lamkaddam, H., Lee, C. P., Lehtipalo, K., Leiminger, M.,

670 Li, Z., Makhmutov, V., Manninen, H. E., Marie, G., Marten, R., Mathot, S., Mauldin, R. L., Mentler, B., Möhler, O., Müller, T., Nie, W., Onnela, A., Petäjä, T., Pfeifer, J., Philippov, M., Ranjithkumar, A., Saiz-Lopez, A., Salma, I., Scholz, W., Schuchmann, S., Schulze, B., Steiner, G., Stozhkov, Y., Tauber, C., Tomé, A., Thakur, R. C., Väisänen, O., Vazquez-Pufleau, M., Wagner, A. C., Wang, Y., Weber, S. K., Winkler, P. M., Wu, Y., Xiao, M., Yan, C., Ye, Q., Ylisirniö, A., Zauner-Wieczorek, M., Zha, Q., Zhou, P., Flagan, R. C., Curtius, J., Baltensperger, U., Kulmala,

675 M., Kerminen, V.-M., Kurtén, T., et al.: Role of iodine oxoacids in atmospheric aerosol nucleation, Science, 371, 589-595, https://doi.org/10.1126/science.abe0298, 2021.

Hudson, P. K., Murphy, D. M., Cziczo, D. J., Thomson, D. S., Gouw, J. A. de, Warneke, C., Holloway, J., Jost, H.J., and Hübler, G.: Biomass-burning particle measurements: Characteristic composition and chemical processing, J. Geophys. Res. Atmospheres, 109, https://doi.org/10.1029/2003JD004398, 2004.

680 Kerminen, V.-M., Teinilä, K., Hillamo, R., and Pakkanen, T.: Substitution of chloride in sea-salt particles by inorganic and organic anions, J. Aerosol Sci., 29, 929-942, https://doi.org/10.1016/S0021-8502(98)00002-0, 1998.

King, S. M., Butcher, A. C., Rosenoern, T., Coz, E., Lieke, K. I., de Leeuw, G., Nilsson, E. D., and Bilde, M.: Investigating Primary Marine Aerosol Properties: CCN Activity of Sea Salt and Mixed Inorganic-Organic Particles, Environ. Sci. Technol., 46, 10405-10412, https://doi.org/10.1021/es300574u, 2012.

685 Laskin, A., Moffet, R. C., Gilles, M. K., Fast, J. D., Zaveri, R. A., Wang, B., Nigge, P., and Shutthanandan, J.: Tropospheric chemistry of internally mixed sea salt and organic particles: Surprising reactivity of $\mathrm{NaCl}$ with weak organic acids, J. Geophys. Res. Atmospheres, 117, https://doi.org/10.1029/2012JD017743, 2012.

Lewis, E. R. and Schwartz, S. E.: Sea Salt Aerosol Production: Mechanisms, Methods, Measurements, and ModelsA Critical Review, American Geophysical Union (AGU), https://doi.org/10.1002/9781118666050.ch1, 2004.

690 Li, J., Pósfai, M., Hobbs, P. V., and Buseck, P. R.: Individual aerosol particles from biomass burning in southern Africa: 2, Compositions and aging of inorganic particles, J. Geophys. Res. Atmospheres, 108, 8484, https://doi.org/10.1029/2002JD002310, 2003.

Lignell, H., Hinks, M. L., and Nizkorodov, S. A.: Exploring matrix effects on photochemistry of organic aerosols, Proc. Natl. Acad. Sci., 111, 13780-13785, https://doi.org/10.1073/pnas.1322106111, 2014.

695 Liu, L., Kong, S., Zhang, Y., Wang, Y., Xu, L., Yan, Q., Lingaswamy, A. P., Shi, Z., Lv, S., Niu, H., Shao, L., Hu, M., Zhang, D., Chen, J., Zhang, X., and Li, W.: Morphology, composition, and mixing state of primary particles from combustion sources — crop residue, wood, and solid waste, Sci. Rep., 7, 5047, https://doi.org/10.1038/s41598017-05357-2, 2017. 
Liu, X., Van Espen, P., Adams, F., Cafmeyer, J., and Maenhaut, W.: Biomass Burning in Southern Africa: Individual Particle Characterization of Atmospheric Aerosols and Savanna Fire Samples, J. Atmospheric Chem., 36, 135-155, https://doi.org/10.1023/A:1006387031927, 2000.

Murphy, D. M., Anderson, J. R., Quinn, P. K., McInnes, L. M., Brechtel, F. J., Kreidenweis, S. M., Middlebrook, A. M., Pósfai, M., Thomson, D. S., and Buseck, P. R.: Influence of sea-salt on aerosol radiative properties in the Southern Ocean marine boundary layer, Nature, 392, 62-65, https://doi.org/10.1038/32138, 1998.

705 Nash, D. G., Baer, T., and Johnston, M. V.: Aerosol mass spectrometry: An introductory review, Int. J. Mass Spectrom., 258, 2-12, https://doi.org/10.1016/j.ijms.2006.09.017, 2006.

Ng, N. L., Canagaratna, M. R., Zhang, Q., Jimenez, J. L., Tian, J., Ulbrich, I. M., Kroll, J. H., Docherty, K. S., Chhabra, P. S., Bahreini, R., Murphy, S. M., Seinfeld, J. H., Hildebrandt, L., Donahue, N. M., DeCarlo, P. F., Lanz, V. A., Prévôt, A. S. H., Dinar, E., Rudich, Y., and Worsnop, D. R.: Organic aerosol components observed in

710 Northern Hemispheric datasets from Aerosol Mass Spectrometry, Atmos Chem Phys, 10, 4625-4641, https://doi.org/10.5194/acp-10-4625-2010, 2010.

Ng, N. L., Canagaratna, M. R., Jimenez, J. L., Chhabra, P. S., Seinfeld, J. H., and Worsnop, D. R.: Changes in organic aerosol composition with aging inferred from aerosol mass spectra, Atmospheric Chem. Phys., 11, 64656474, https://doi.org/10.5194/acp-11-6465-2011, 2011.

715 Pistone, K., Redemann, J., Doherty, S., Zuidema, P., Burton, S., Cairns, B., Cochrane, S., Ferrare, R., Flynn, C., Freitag, S., Howell, S. G., Kacenelenbogen, M., LeBlanc, S., Liu, X., Schmidt, K. S., Sedlacek III, A. J., SegalRozenhaimer, M., Shinozuka, Y., Stamnes, S., van Diedenhoven, B., Van Harten, G., and Xu, F.: Intercomparison of biomass burning aerosol optical properties from in situ and remote-sensing instruments in ORACLES-2016, Atmospheric Chem. Phys., 19, 9181-9208, https://doi.org/10.5194/acp-19-9181-2019, 2019.

720 Pósfai, M., Simonics, R., Li, J., Hobbs, P. V., and Buseck, P. R.: Individual aerosol particles from biomass burning in southern Africa: 1. Compositions and size distributions of carbonaceous particles, J. Geophys. Res. Atmospheres, 108, https://doi.org/10.1029/2002JD002291, 2003.

Redemann, J., Wood, R., Zuidema, P., Doherty, S. J., Luna, B., LeBlanc, S. E., Diamond, M. S., Shinozuka, Y., Chang, I. Y., Ueyama, R., Pfister, L., Ryoo, J., Dobracki, A. N., da Silva, A. M., Longo, K. M., Kacenelenbogen, M.

725 S., Flynn, C. J., Pistone, K., Knox, N. M., Piketh, S. J., Haywood, J. M., Formenti, P., Mallet, M., Stier, P., Ackerman, A. S., Bauer, S. E., Fridlind, A. M., Carmichael, G. R., Saide, P. E., Ferrada, G. A., Howell, S. G., Freitag, S., Cairns, B., Holben, B. N., Knobelspiesse, K. D., Tanelli, S., L’Ecuyer, T. S., Dzambo, A. M., Sy, O. O., McFarquhar, G. M., Poellot, M. R., Gupta, S., O’Brien, J. R., Nenes, A., Kacarab, M. E., Wong, J. P. S., SmallGriswold, J. D., Thornhill, K. L., Noone, D., Podolske, J. R., Schmidt, K. S., Pilewskie, P., Chen, H., Cochrane, S.

730 P., Sedlacek, A. J., Lang, T. J., Stith, E., Segal-Rozenhaimer, M., Ferrare, R. A., Burton, S. P., Hostetler, C. A., Diner, D. J., Platnick, S. E., Myers, J. S., Meyer, K. G., Spangenberg, D. A., Maring, H., and Gao, L.: An overview of the ORACLES (ObseRvations of Aerosols above CLouds and their intEractionS) project: aerosol-cloud-radiation interactions in the Southeast Atlantic basin, Aerosols/Field Measurements/Troposphere/Physics (physical properties and processes), https://doi.org/10.5194/acp-2020-449, 2020.

735 Redemann, J., Wood, R., Zuidema, P., Doherty, S. J., Luna, B., LeBlanc, S. E., Diamond, M. S., Shinozuka, Y., Chang, I. Y., Ueyama, R., Pfister, L., Ryoo, J.-M., Dobracki, A. N., da Silva, A. M., Longo, K. M., Kacenelenbogen, M. S., Flynn, C. J., Pistone, K., Knox, N. M., Piketh, S. J., Haywood, J. M., Formenti, P., Mallet, M., Stier, P., Ackerman, A. S., Bauer, S. E., Fridlind, A. M., Carmichael, G. R., Saide, P. E., Ferrada, G. A., Howell, S. G., Freitag, S., Cairns, B., Holben, B. N., Knobelspiesse, K. D., Tanelli, S., L’Ecuyer, T. S., Dzambo, A. M., Sy,

740 O. O., McFarquhar, G. M., Poellot, M. R., Gupta, S., O’Brien, J. R., Nenes, A., Kacarab, M., Wong, J. P. S., SmallGriswold, J. D., Thornhill, K. L., Noone, D., Podolske, J. R., Schmidt, K. S., Pilewskie, P., Chen, H., Cochrane, S. P., Sedlacek, A. J., Lang, T. J., Stith, E., Segal-Rozenhaimer, M., Ferrare, R. A., Burton, S. P., Hostetler, C. A., Diner, D. J., Seidel, F. C., Platnick, S. E., Myers, J. S., Meyer, K. G., Spangenberg, D. A., Maring, H., and Gao, L.: An overview of the ORACLES (ObseRvations of Aerosols above CLouds and their intEractionS) project: aerosol-

745 cloud-radiation interactions in the southeast Atlantic basin, Atmospheric Chem. Phys., 21, 1507-1563, https://doi.org/10.5194/acp-21-1507-2021, 2021. 
Reid, J. P., Bertram, A. K., Topping, D. O., Laskin, A., Martin, S. T., Petters, M. D., Pope, F. D., and Rovelli, G.: The viscosity of atmospherically relevant organic particles, Nat. Commun., 9, 956, https://doi.org/10.1038/s41467018-03027-z, 2018.

750 Roberts, G., Wooster, M. J., Perry, G. L. W., Drake, N., Rebelo, L.-M., and Dipotso, F.: Retrieval of biomass combustion rates and totals from fire radiative power observations: Application to southern Africa using geostationary SEVIRI imagery, J. Geophys. Res. Atmospheres, 110, https://doi.org/10.1029/2005JD006018, 2005.

Roberts, G., Wooster, M. J., and Lagoudakis, E.: Annual and diurnal african biomass burning temporal dynamics, Biogeosciences, 6, 849-866, https://doi.org/10.5194/bg-6-849-2009, 2009.

755 Sanchez-Marroquin, A., Hedges, D. H. P., Hiscock, M., Parker, S. T., Rosenberg, P. D., Trembath, J., Walshaw, R., Burke, I. T., McQuaid, J. B., and Murray, B. J.: Characterisation of the filter inlet system on the FAAM BAe-146 research aircraft and its use for size-resolved aerosol composition measurements, Atmospheric Meas. Tech., 12, 5741-5763, https://doi.org/10.5194/amt-12-5741-2019, 2019.

Sedlacek III, A. J., Buseck, P. R., Adachi, K., Onasch, T. B., Springston, S. R., and Kleinman, L.: Formation and evolution of tar balls from northwestern US wildfires, Atmospheric Chem. Phys., 18, 11289-11301, https://doi.org/10.5194/acp-18-11289-2018, 2018.

Seinfeld, J. H. and Pandis, S. N.: Atmospheric Chemistry and Physics: From Air Pollution to Climate Change, John Wiley \& Sons, 1119 pp., 2012.

Signorell, R. and Reid, J. (Eds.): Fundamentals and Applications in Aerosol Spectroscopy, CRC Press, https://doi.org/10.1201/b10417, 2011.

Stein, A. F., Draxler, R. R., Rolph, G. D., Stunder, B. J. B., Cohen, M. D., and Ngan, F.: NOAA's HYSPLIT Atmospheric Transport and Dispersion Modeling System, Bull. Am. Meteorol. Soc., 96, 2059-2077, https://doi.org/10.1175/BAMS-D-14-00110.1, 2015.

Taylor, J. W., Wu, H., Szpek, K., Bower, K., Crawford, I., Flynn, M. J., Williams, P. I., Dorsey, J., Langridge, J. M., Cotterell, M. I., Fox, C., Davies, N. W., Haywood, J. M., and Coe, H.: Absorption closure in highly aged biomass burning smoke, Atmospheric Chem. Phys., 20, 11201-11221, https://doi.org/10.5194/acp-20-11201-2020, 2020.

Vakkari, V., Beukes, J. P., Dal Maso, M., Aurela, M., Josipovic, M., and van Zyl, P. G.: Major secondary aerosol formation in southern African open biomass burning plumes, Nat. Geosci., 11, 580-583, https://doi.org/10.1038/s41561-018-0170-0, 2018.

775 Wong, J. P. S., Zhou, S., and Abbatt, J. P. D.: Changes in Secondary Organic Aerosol Composition and Mass due to Photolysis: Relative Humidity Dependence, J. Phys. Chem. A, 119, 4309-4316, https://doi.org/10.1021/jp506898c, 2015.

Wu, H., Taylor, J. W., Szpek, K., Langridge, J. M., Williams, P. I., Flynn, M., Allan, J. D., Abel, S. J., Pitt, J., Cotterell, M. I., Fox, C., Davies, N. W., Haywood, J., and Coe, H.: Vertical variability of the properties of highly 780 aged biomass burning aerosol transported over the southeast Atlantic during CLARIFY-2017, Atmospheric Chem. Phys., 20, 12697-12719, https://doi.org/10.5194/acp-20-12697-2020, 2020.

Zheng, G., Wang, Y., Wood, R., Jensen, M. P., Kuang, C., McCoy, I. L., Matthews, A., Mei, F., Tomlinson, J. M., Shilling, J. E., Zawadowicz, M. A., Crosbie, E., Moore, R., Ziemba, L., Andreae, M. O., and Wang, J.: New particle formation in the remote marine boundary layer, Nat. Commun., 12, 527, https://doi.org/10.1038/s41467-020-207731,2021

Zuidema, P., Sedlacek III, A. J., Flynn, C., Springston, S., Delgadillo, R., Zhang, J., Aiken, A. C., Koontz, A., and Muradyan, P.: The Ascension Island boundary layer in the remote southeast Atlantic is often smoky, Geophys. Res. Lett., 45, https://doi.org/10.1002/2017GL076926, 2018. 
Table 1 Filter IDs, ancillary online aerosol data, location, altitude, backtrajectory-based time from fire as detailed in the text, and in-cloud time over previous 24 hours

\begin{tabular}{|c|c|c|c|c|c|c|c|c|c|c|c|c|c|c|c|c|}
\hline $\begin{array}{c}\text { Campaign } \\
\text { and year }\end{array}$ & Filter & Date & $\begin{array}{l}\text { Particles } \\
\text { analyzed }\end{array}$ & \begin{tabular}{|c|} 
Latitude \\
$\left({ }^{\circ}\right)$
\end{tabular} & $\begin{array}{c}\text { Longitude } \\
\left({ }^{\circ}\right)\end{array}$ & \begin{tabular}{|c}
$\begin{array}{c}\text { Altitude } \\
(\mathrm{m})\end{array}$ \\
\end{tabular} & $\begin{array}{c}\text { Org } \\
\left(\mu \mathrm{g} / \mathrm{cm}^{-3}\right) \\
\end{array}$ & $\begin{array}{c}\begin{array}{c}\mathrm{SO} 4 \\
\left(\mathrm{gg} / \mathrm{cm}^{-3}\right)\end{array} \\
\end{array}$ & $\begin{array}{c}\mathrm{NO3} \\
\left(\mu \mathrm{g} / \mathrm{cm}^{-3}\right)\end{array}$ & $\begin{array}{c}\mathrm{NH} 4 \\
\left(\mu \mathrm{g} / \mathrm{cm}^{-3}\right)\end{array}$ & $\begin{array}{c}\mathrm{BC} \\
\left(\mu \mathrm{g} / \mathrm{cm}^{-3}\right) \\
\end{array}$ & \begin{tabular}{|c|}
$\mathrm{BC}$ \\
(particles \\
$\left(\mathrm{cm}^{-3}\right)$ \\
\end{tabular} & $\begin{array}{c}\mathrm{CO} \\
\text { (ppbv) }\end{array}$ & $\begin{array}{c}\text { Cloud time in } \\
\text { 24hrs } \\
\text { (hours) }\end{array}$ & \begin{tabular}{|c|}
$\begin{array}{c}\text { Above or } \\
\text { Below } \\
\text { cloud }\end{array}$ \\
\end{tabular} & \begin{tabular}{|c|} 
Time \\
from fire \\
(days) \\
\end{tabular} \\
\hline $\begin{array}{c}\text { ORACLES } \\
2017 \\
\end{array}$ & RF11Filter5 & $8 / 30 / 2017$ & 47 & -9.47 & 5 & 3505 & 20.5 & 1.5 & 3.1 & 1.3 & 3.8 & 1162 & 395 & 0 & Above & 2 \\
\hline \multirow{15}{*}{$\begin{array}{c}\text { ORACLES } \\
2018\end{array}$} & RF02_1 & 9/30/2018 & 23 & -7.64 & 5 & 894 & 1.1 & 0.5 & 0.1 & 0.1 & 0.2 & 56 & 110 & 9.35 & Below & 5 \\
\hline & RF02_2 & 9/30/2018 & 35 & -7.82 & 5.03 & 2606 & 6.6 & 0.9 & 0.3 & 0.2 & 0.9 & 273 & 210 & 6.55 & Above & 1 \\
\hline & RF03 & $10 / 2 / 2018$ & 59 & -7.67 & 5.5 & 982 & & & & & 1.2 & 346 & 156 & 18.08 & Above & 6 \\
\hline & RF04 & 10/3/2018 & 65 & -6.75 & 7 & 1195 & 0.5 & 0.4 & 0.0 & 0.1 & 0.3 & 117 & 120 & 6.58 & Above & 6 \\
\hline & RF05_1 & $10 / 5 / 2018$ & 55 & -9.5 & 6.17 & 943 & 0.7 & 0.5 & 0.1 & 0.2 & 1 & 297 & 154 & 11.29 & Above & 6 \\
\hline & RF05_2 & $10 / 5 / 2018$ & 64 & -9.5 & 6.21 & 378 & 0.2 & 0.2 & 0.0 & 0.1 & 0.5 & 119 & 106 & 8.42 & Below & marine \\
\hline & RF05_3 & $10 / 5 / 2018$ & 37 & -9.5 & 6.11 & 3247 & 6.4 & 1.2 & 0.5 & 0.4 & 0.9 & 294 & 210 & 0 & Above & 1 \\
\hline & RF06_1 & $10 / 7 / 2018$ & 49 & -8.91 & 5 & 2444 & 6 & 1.1 & 0.4 & 0.4 & 1.3 & 421 & 248 & 0 & Above & 2 \\
\hline & RF06_2 & $\begin{array}{l}10 / 7 / 2018 \\
\end{array}$ & 39 & $\begin{array}{l}-6.86 \\
\end{array}$ & 5 & 2570 & 2.3 & 0.6 & 0.1 & 0.2 & 0.5 & 193 & 173 & 0 & Above & 2 \\
\hline & RF07_1 & $10 / 10 / 2018$ & 43 & -12.77 & 5.01 & 1091 & 0.6 & 0.3 & 0.0 & 0.1 & 0.5 & 159 & 121 & 2.59 & Above & 6 \\
\hline & RF07_2 & $10 / 10 / 2018$ & 29 & -7.39 & 5 & 159 & 0.3 & 0.2 & 0.0 & 0.0 & 0.4 & 108 & 123 & 0.18 & Below & marine \\
\hline & RF09 & $10 / 15 / 2018$ & 56 & -11.35 & 5 & 1307 & 1.2 & 0.5 & 0.1 & 0.1 & 1 & 265 & 158 & 0.5 & Above & 7 \\
\hline & RF10 & $10 / 17 / 2018$ & 66 & -7.18 & 10.5 & 1986 & 18.5 & 3 & 2.6 & 1.4 & 2.3 & 807 & 417 & 2.25 & Above & 1 \\
\hline & RF11 & \begin{tabular}{|l|}
$10 / 19 / 2018$ \\
\end{tabular} & 62 & -7.95 & 9 & 3027 & 3.7 & 0.6 & 0.3 & 0.2 & 0.9 & 292 & 190 & 0.08 & Above & 2 \\
\hline & RF13 & $10 / 23 / 2018$ & 33 & -5.01 & -0.68 & 1127 & 0.1 & 0.1 & 0.0 & 0.0 & 0.1 & 42 & 118 & 6.94 & Above & 4 \\
\hline \multirow{14}{*}{$\begin{array}{c}\text { CLARIFY } \\
2017\end{array}$} & Gold_1 & \begin{tabular}{|l|}
$8 / 17 / 2017$ \\
\end{tabular} & 49 & $\begin{array}{ll}-8.8 \\
\end{array}$ & -11.52 & 323 & 4.1 & 1.9 & 0.2 & 0.7 & 0.5 & 195 & 108 & 0 & Below & marine \\
\hline & Gold_8 & $8 / 22 / 2017$ & 27 & -8.46 & -13.43 & 3902 & 6.9 & 1.3 & 1.4 & 1.0 & 1.2 & 380 & 204 & 20.77 & Above & 7 \\
\hline & Gold_9 & $8 / 23 / 2017$ & 39 & -5.67 & -12.42 & 2813 & 18.8 & 2.9 & 3.1 & 2.0 & 3 & 934 & 329 & 0 & Above & 4 \\
\hline & Gold_10 & $8 / 24 / 2017$ & 42 & -8.37 & -15.24 & 2918 & 3.9 & 0.6 & 0.3 & 0.3 & 0.8 & 232 & 158 & 0 & Above & 5 \\
\hline & Gold_11 & $8 / 24 / 2017$ & 54 & -7.7 & -13.85 & 319 & 0.3 & 0.3 & 0.0 & 0.1 & 0.1 & 17 & 70 & 0 & Below & 15 \\
\hline & Gold_14 & $8 / 28 / 2017$ & 47 & -8.26 & -13.74 & 2845 & & & & & & 683 & 262 & 0 & Above & 6 \\
\hline & Gold_15 & $8 / 28 / 2017$ & 22 & -8.28 & -13.66 & 329 & & & & & 1 & 287 & 158 & 0.3 & Below & marine \\
\hline & Gold_18 & $8 / 29 / 2017$ & 32 & -8.69 & -12.47 & 332 & & & & & 0.5 & 174 & 119 & 0 & Below & marine \\
\hline & Gold_19 & $8 / 30 / 2017$ & 57 & -8 & -17.08 & 1969 & 5.7 & 1.6 & 0.9 & 0.8 & 1.8 & 535 & 212 & 0.38 & Above & 7 \\
\hline & Gold_20 & $8 / 30 / 2017$ & 30 & -8.03 & -17.3 & 329 & 3.6 & 1.2 & 0.2 & 0.5 & 0.7 & 225 & 130 & 0 & Below & marine \\
\hline & Gold_21 & 9/7/2017 & 43 & -8.32 & -18.48 & 2357 & & & & & 1.5 & 436 & 177 & 0 & Above & 6 \\
\hline & Gold_22 & $9 / 2 / 2017$ & 43 & -5.66 & -13 & 2139 & 2.1 & 0.6 & 0.2 & 0.3 & 0.7 & 208 & 128 & 0 & Below & 9 \\
\hline & Gold_23 & 9/2/2017 & 44 & -6.14 & -13.52 & 3500 & 12.2 & 1.3 & 2.4 & 1.3 & 2.5 & 750 & 273 & 0 & Above & 4 \\
\hline & Gold_24 & 9/4/2017 & 24 & $\begin{array}{l}-7.91 \\
\end{array}$ & -12.72 & 1950 & 13.4 & 2.3 & 1.9 & 1.4 & 3.6 & 968 & 331 & 7.84 & Above & 4 \\
\hline
\end{tabular}



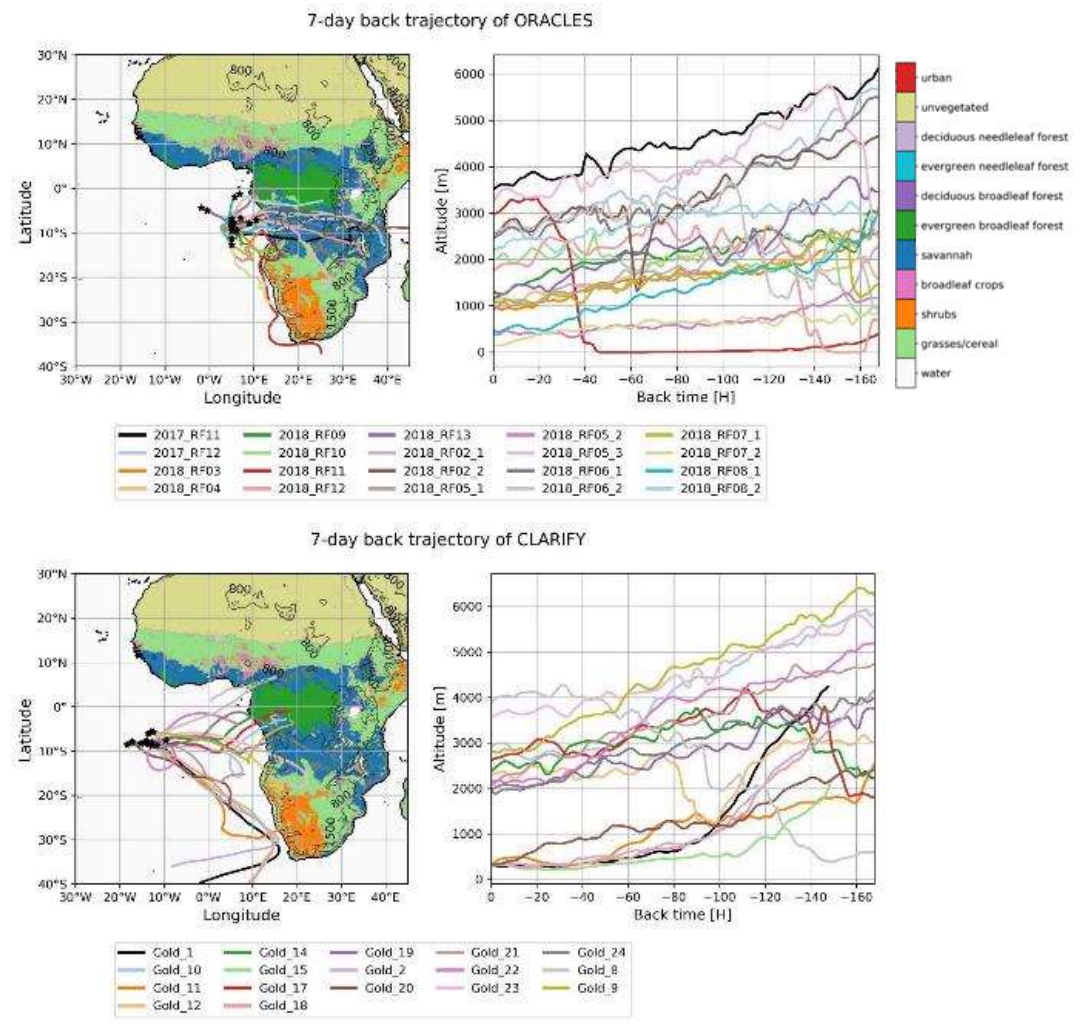

795

Figure 1 The location of filter sampling and back trajectories related to each filter, including altitude for ORACLES 2017-18 (upper panel), and CLARIFY 2017 (lower panel). Map colors relate to MODIS land cover types.
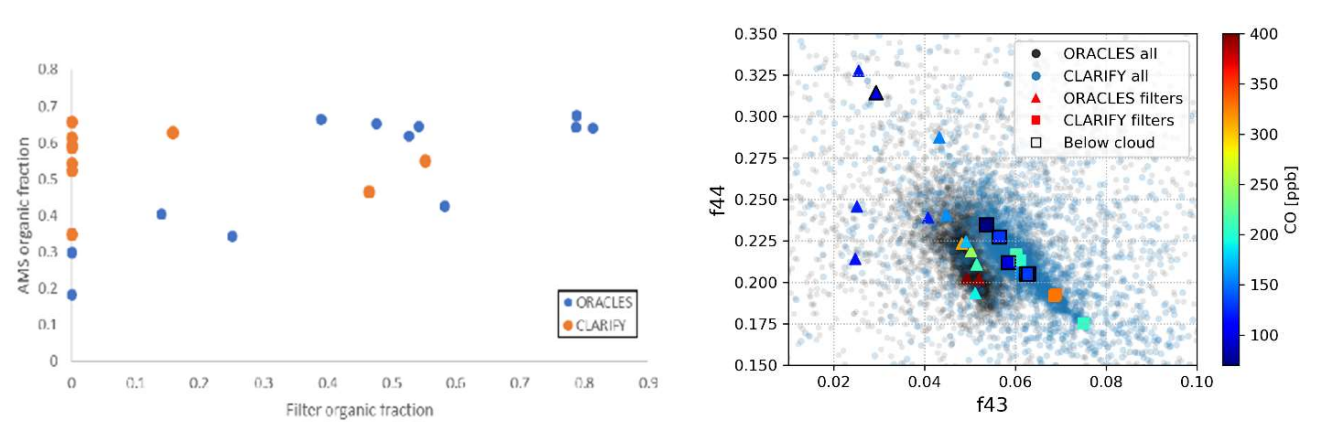

Figure 2 (left) AMS organic fraction vs filter organic fraction and (right) f44 vs $\mathbf{f 4 3}$ space for ORACLES and CLARIFY campaigns with filters marked as triangles for ORACLES and squares for CLARIFY. Samples collected below-cloud are outlined with a black border. 

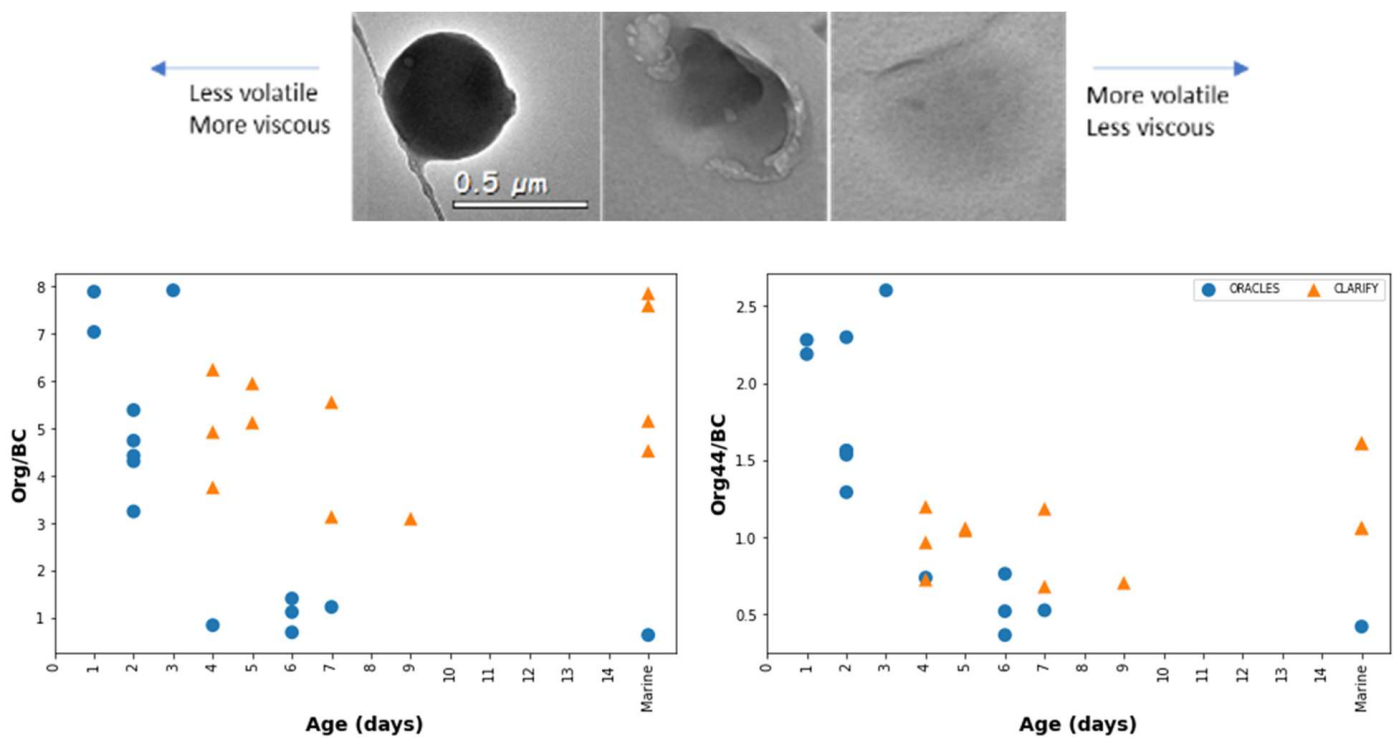

Figure 3 Example of different viscosity/volatility organic aerosol (top panel) showing more round and viscous particles for ORACLES (on the left), and more volatile for CLARIFY (middle and right top panels) and Org/BC and Org44/BC ratios with time from fire source (bottom panel)

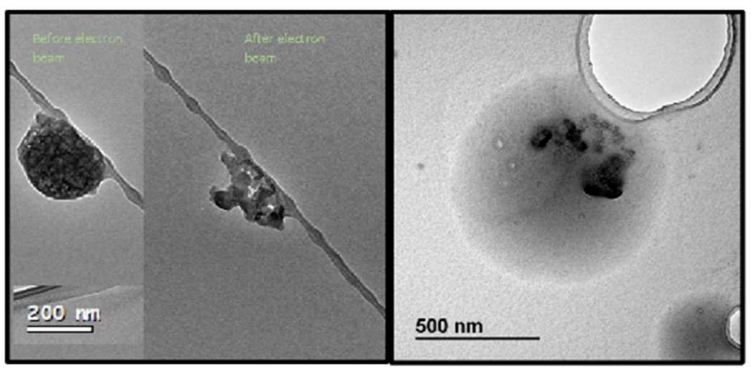

Figure 4 Potassium salt in a core-shell morphology around a refractory BC core (left) and organic with interstitial K-salt (right). Note the difference in scale between the two images.

Table 2 Black Carbon Mixing State by campaign. FT/BL, BC-Salt and BC-Organic refer to internally mixed particles

\begin{tabular}{|r|c|c|c|}
\hline & BC-Salt & BC-Organic & BC- external \\
\hline ORACLES BL & 0.78 & 0.00 & 0.22 \\
\hline ORACLES FT & 0.53 & 0.31 & 0.16 \\
\hline CLARIFY BL & 0.50 & 0.29 & 0.21 \\
\hline CLARIFY FT & 0.67 & 0.07 & 0.26 \\
\hline
\end{tabular}




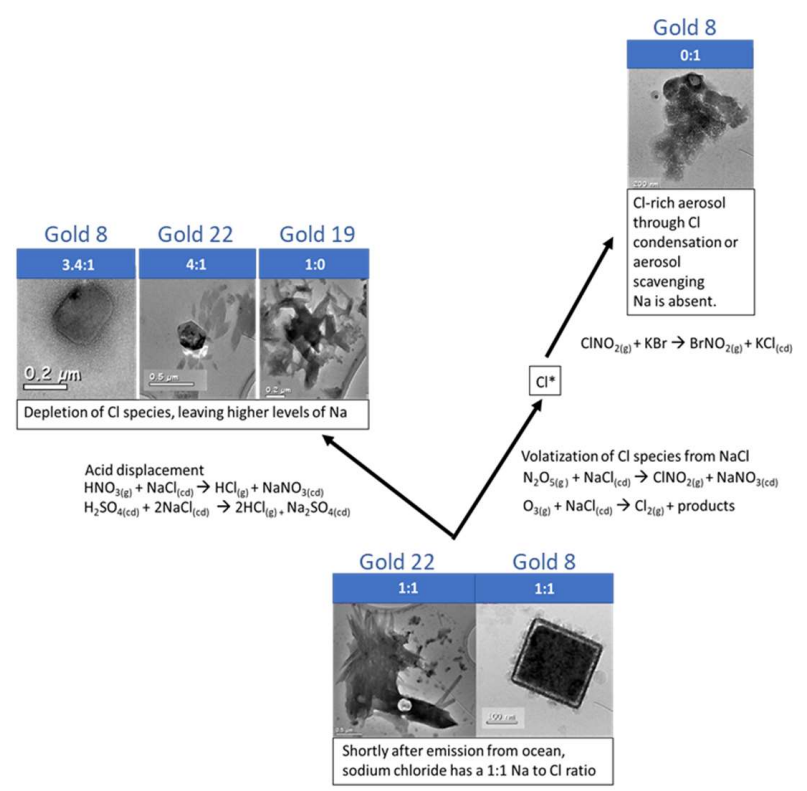

Figure 5 Schematic showing different stages of sea salt conversion with example mechanisms. The particles are from CLARIFY filters and range from sea salts which have been freshly emitted to Cl-depleted particles containing nitrates and sulfates. $\mathrm{Cl}$ aerosol formation is also shown. $\mathrm{Na}$ :Cl ratios showing depletion of $\mathrm{Cl}$ with sea salt conversion are shown in the bar above each particle image.
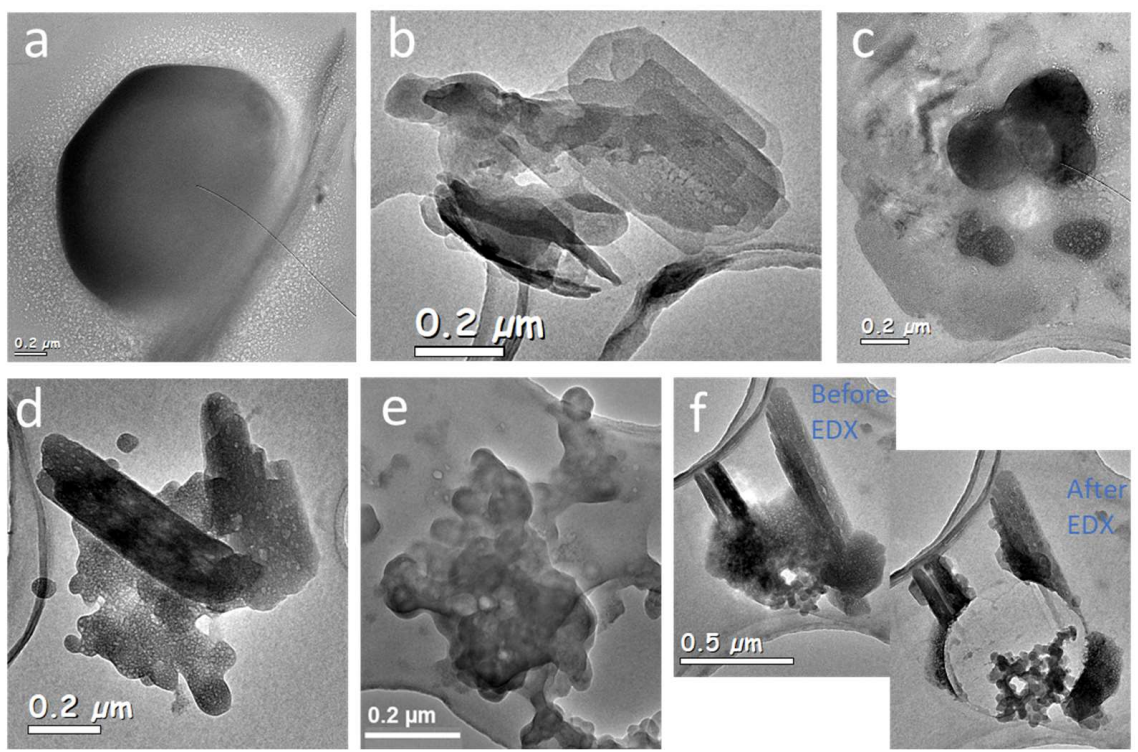

Figure 6 Assorted sea salt particles. (a) 1.5 micron rounded NaCl; Gold 1 (b) CaSO4; Gold 1 (c) NaCl and Mg; Gold 1 (d) Na2SO4 with K; Gold 1 (e) NaNO3 mixed with BC; Gold 24 (f) BC encapsulated in Na2SO4 with K ; Gold1 
Table 3 Na dominant aerosols on CLARIFY filters with sampling location, $C O$ levels, time forum source, and percentage of particles on the filter with either $\mathrm{Na}$ or $\mathrm{Cl}$. The ratios represent the weight percent ratio per particle, averaged across all particles with the elements of interest on each filter.

\begin{tabular}{|c|c|c|c|c|c|c|c|c|c|c|}
\hline & $\begin{array}{c}\text { Avitude } \\
(\mathrm{m})\end{array}$ & $\begin{array}{l}\text { Above/ } \\
\text { Below } \\
\text { doud }\end{array}$ & $\begin{array}{c}c 0 \\
\text { (ppbv) }\end{array}$ & $\begin{array}{l}\text { Time from } \\
\text { fire (dars) }\end{array}$ & \begin{tabular}{|l} 
Partides with \\
Naor Cl (\%) \\
\end{tabular} & $\begin{array}{l}\text { Avg Na } \\
\text { w\% }\end{array}$ & Avg Cl wt\% & $\mathrm{Na} / \mathrm{Cl}$ & $\mathrm{Na} / \mathrm{s}$ & Representative partide and filter summary \\
\hline Gold_1 & 323 & Below & 108 & marine & 98 & 10.6 & 10.7 & 7.2 & 5.2 & $\begin{array}{l}\mathrm{Na} a n d \mathrm{Cl} \text { with vary levels of } \mathrm{Cl} \text { depletion; some } \mathrm{Na} \text { withS; } \\
\text { lage } \mathrm{NaCl} \text { particles, } \mathrm{BC} \text { mixed with } \mathrm{NaSO} 4\end{array}$ \\
\hline Gold_8 & 3902 & Above & 204 & 7 & 100 & 13.7 & 12.6 & 4.3 & NA & $\begin{array}{l}\text { Mostly Cl particles without Naalthough some } \mathrm{NaCl} 1: 1 \\
\mathrm{cryszals}\end{array}$ \\
\hline Gold_9 & 2813 & Above & 329 & 4 & 37 & 5.8 & & NA & 13.1 & NoCl prsent; Na mixed with BC and BB salts, sodium nitrae \\
\hline Gold_10 & 2918 & Above & 158 & 5 & 74 & 5.4 & & NA & 5.4 & $\mathrm{NoCl}$ present; sodium sulfate, $\mathrm{BC}$ mixed with $\mathrm{Na}$ \\
\hline Gold_11 & 319 & Below & 70 & 15 & 80 & 19.2 & 4.7 & 6.1 & 8.1 & $\begin{array}{l}\mathrm{NaCl} \text {, ammonium chloride, sodium sulfate, Na with depleted } \\
\mathrm{Cl} \text { all present }\end{array}$ \\
\hline Gold_19 & 1969 & Above & 212 & 7 & 29 & 3.7 & & NA & 20 & $\begin{array}{l}\text { Nasulfate, } \mathrm{BC} \text { mixed with Na sulfae; no Cl, BC with Na, P, S, } \\
K, \mathrm{Ca}\end{array}$ \\
\hline Gold_20 & 329 & Below & 130 & marine & 90 & 3.4 & 0.6 & 12.0 & 3.5 & $\begin{array}{l}\text { BC mixed with Na; } \mathrm{NaS} \text { crystals; } \mathrm{NaCl} \text { but most particles } \mathrm{Cl} \\
\text { depleted }\end{array}$ \\
\hline Gold_21 & 2357 & Above & $1 \pi$ & 6 & 36 & 1.1 & & NA & 0.8 & Trace amounts of sodium, no marine salts noted \\
\hline Gold_22 & 2139 & Below & 128 & 9 & 77 & 12.5 & 8.7 & 3.9 & 3.3 & $\mathrm{Na} \mathrm{SO}_{4}, \mathrm{NaCl}$ \\
\hline Gold_23 & 3500 & Above & 273 & 4 & 63 & 7.6 & 0.5 & 20.2 & 3.7 & Low levels of $\mathrm{Cl}, \mathrm{BC}$ mixed with $\mathrm{Na}, \mathrm{S}, \mathrm{K}$ \\
\hline Gold_24 & 1950 & Above & 331 & 4 & 77 & 23 & & NA & 1.9 & Sodium nitrate mixed with $B C$ \\
\hline
\end{tabular}


Table 4 Cl dominant aerosol on CLARIFY filters

\begin{tabular}{|l|c|c|c|c|c|}
\hline Filter ID & $\begin{array}{c}\text { Altitude } \\
(\mathrm{m})\end{array}$ & $\begin{array}{c}\text { Above/ } \\
\text { Below } \\
\text { cloud }\end{array}$ & $\begin{array}{c}\text { CO } \\
\text { (ppbv) }\end{array}$ & $\begin{array}{c}\text { Time from } \\
\text { fire (days) }\end{array}$ & Particle image \& description \\
\hline Gold_14 & 2845 & Above & 262 & 6 & N and Cl dominant \\
spectra; uniform \\
particles across filter
\end{tabular}
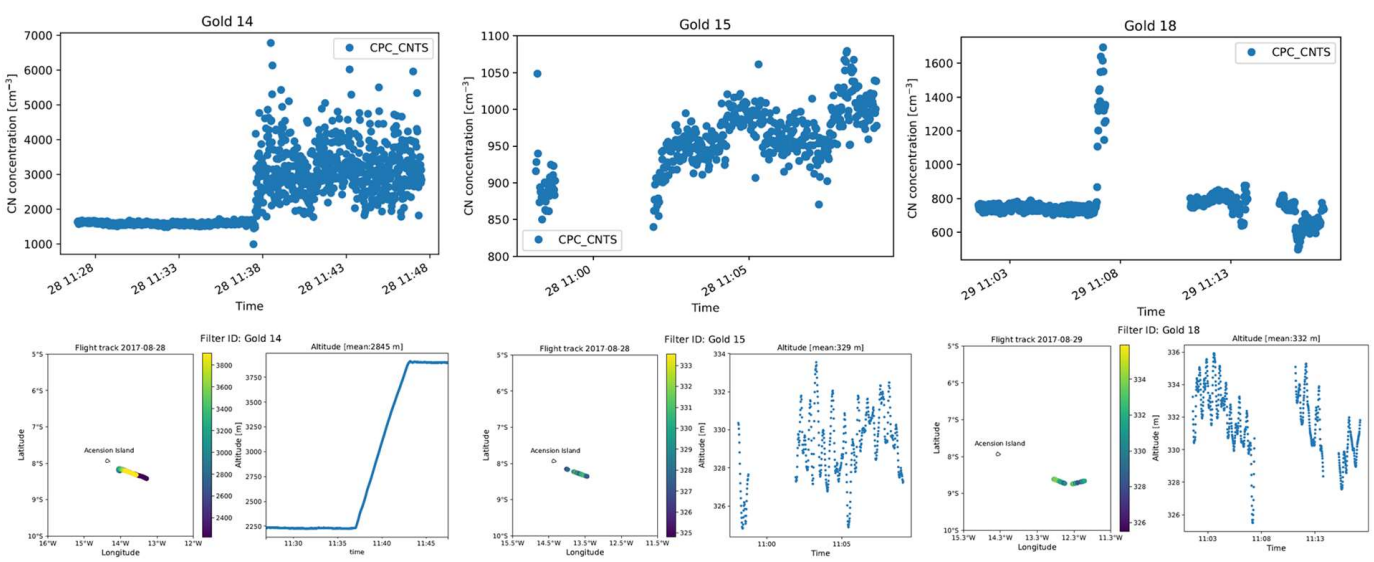

Figure 7 (upper panel) particle count concentration during filter collection time for the three Cl dominant filters, Gold14, Gold15, and Gold18, as detailed in Table 4, and (lower panel-left column) flight track, and (lower panel-right column) altitude 
a)

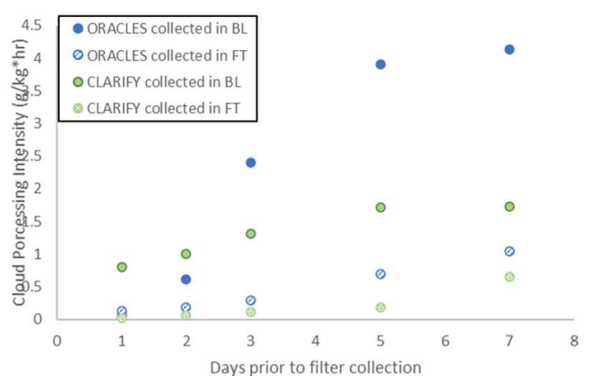

c)

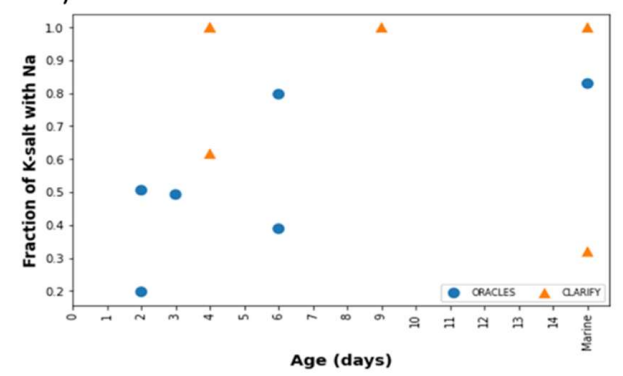

b)

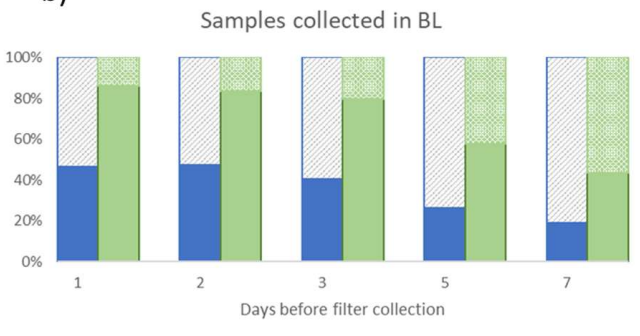

- ORACLES BL gORACLESFT aCLARIFY BL @CLARIFY

d) Samples collected in FT

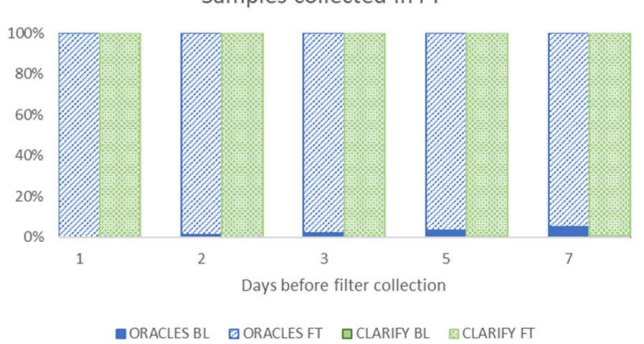

Figure 8 Panel a) BL and FT ORACLES and CLARIFY cloud processing intensity b) Time spent in BL and FT for samples collected in the BL in the days prior to filter collection C) Fraction of K-salt, per filter, mixed with Na d) Fractional time spent in BL and FT for samples collected in the FT in the days prior to filter collection

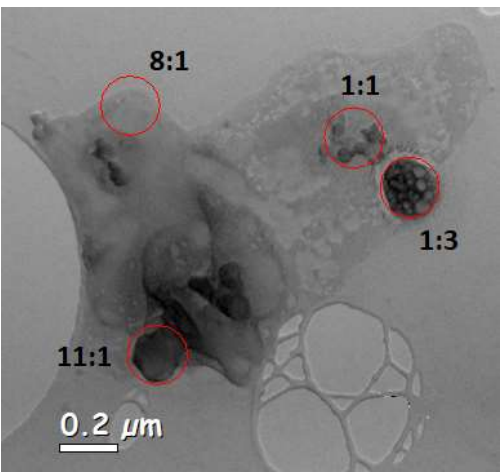

Figure 9 Aqueous K-salt particle with varying levels of Na throughout particle, with Na:K weight ratio designated in red 
https://doi.org/10.5194/acp-2021-724

Preprint. Discussion started: 21 September 2021

(c) Author(s) 2021. CC BY 4.0 License.

(c) (1)

Atmospheric

Chemistry

and Physics

Discussions

850

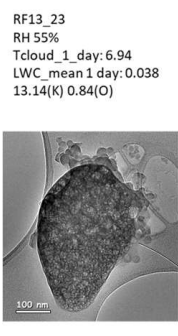

RF5_Filter2_63

$\mathrm{RH} 30 \%$

Tcloud_1_day: 8.42

$1.48(\mathrm{~S}) 14.93(\mathrm{~K}) 5.18(\mathrm{O})$

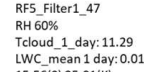
$15.56(\mathrm{~S}) 25.01(\mathrm{~K})$
$6.7(\mathrm{Na}) 18.7(0)$
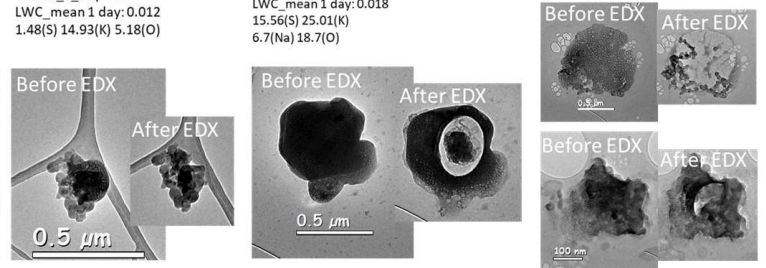

RF3_43

Tcloud 1 day: 18.08

LWC mean 1 day: 0.052

$5.87(\mathrm{~S}) 6.74(\mathrm{~K}) 5.24(\mathrm{O}$

RF3_31
RH 60\%

RH $60 \%$

LWC_mean 1 day: 0.052

Time in cloud (1 day prior to filter collection)

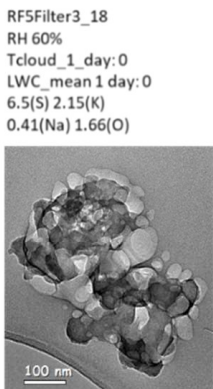

RF10 45

RH $75 \%$

Tcloud_ 1 day: 2.25

IWC mean 1 day: 0.006

$5(S) 2.62(K) 2.24(0)$

RF3_29

Tcloud_1_day: 9.35 Tcloud_1_day: 11.29

0.052 LWC mean 1 day: 0.018

$4.27(\mathrm{~S}) 2.81(\mathrm{~K}) 1.41(\mathrm{O}) \quad 4.88(\mathrm{~S}) 2.48(\mathrm{~K}) 3.44(\mathrm{Na})$
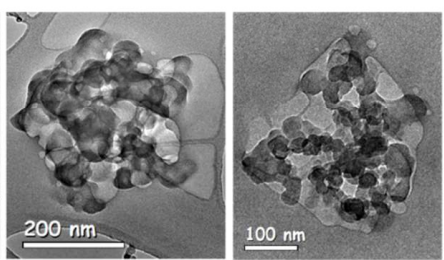

$7.5(0)$

Time in cloud (1 day prior to filter collection)

Figure 10 Potassium salt mixed with BC (top panel) and sulfur-organic and BC (bottom panel) as a function of time in cloud in the 24 hours prior to filter collection. 


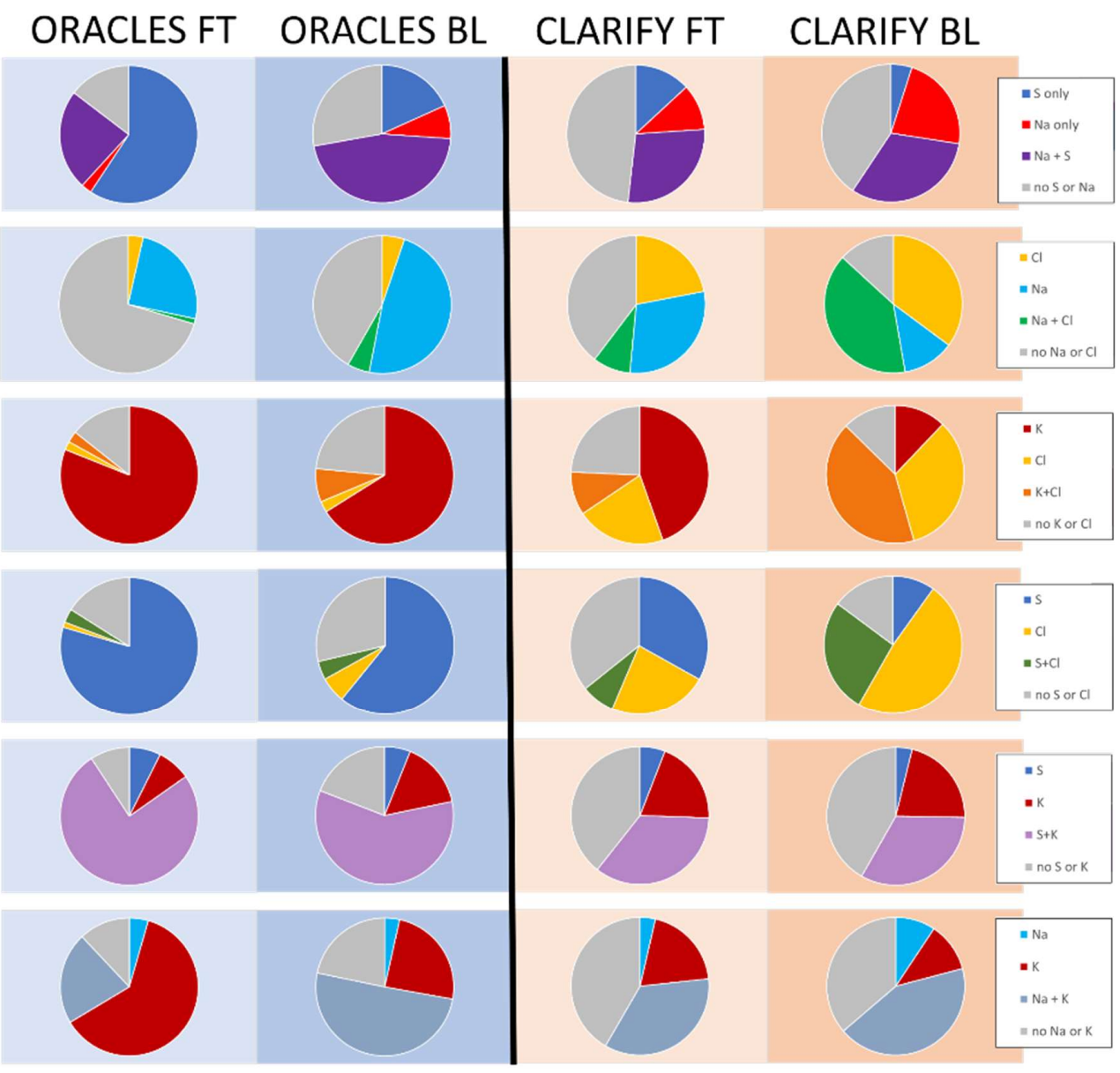

Figure 11 Elemental mixing states for select elemental pairs for CLARIFY (two left columns) and ORACLES (two right columns), separated by filter collection in the free troposphere and boundary layer 